\title{
PEMILIHAN LOKASI KAWASAN KONSERVASI MANGROVE DENGAN PENDEKATAN SIG PARTISIPATIF DI WILAYAH PANTAI KABUPATEN DEMAK
}

\author{
Elida Nurrohmah ${ }^{1}$, Sunarto ${ }^{2}$, dan Nurul Khakhim ${ }^{3}$
}

Magister Perencanaan dan Pengelolaan Pesisir dan Daerah Aliran Sungai, FakultasGeografi, ${ }^{2,3}$, Universitas Gadjah Mada, Yogyakarta, Indonesia

uswatunkh21@gmail.com

Diterima : Desember 2015 ; Direvisi : Juni 2016; Dipubikasikan: September 2016

\begin{abstract}
ABSTRAK Penentuan lokasi kawasan konservasi berkaitan dengan keputusan penggunaan lahan, yang melibatkan banyak aktor dan faktor. Analisis yang bersifat multifaktor dapat diselesaikan dengan memanfaatkan Sistem Informasi Geografis (SIG), namun penilaiannya hanya berdasarkan pada penilaian tunggal dari seseorang ataupun suatu institusi. Penelitian ini berusaha untuk mengintegrasikan analisis yang bersifat multiaktor dan multifaktor melalui analisis multikriteria dengan SIG berbasis partisipasi masyarakat untuk memilih lokasi kawasan konservasi mangrove. Kriteria yang dipertimbangkan dalam pemilihan lokasi ini meliputi aspek (i) fisik, (ii) sosial, (iii) pembiayaan, dan (iv) ancaman. Kriteria aspek fisik disusun berdasarkan hasil analisis kesesuaian lahan untuk mangrove. Kriteria aspek sosial, pembiayaan, dan ancaman disusun berdasarkan data sosial kependudukan yang diperoleh melalui studi literatur. Partisipasi masyarakat dalam proses pemilihan lokasi ini terletak pada penentuan bobot kriteria melalui perbandingan kriteria berpasangan dan dianalisis dengan teknik Analytical Hierarchial Process (AHP), serta penggalian informasi lokal melalui pemetaan partisipatif. Bobot kriteria setiap pemangku kepentingan diintegrasikan dengan data spasial melalui operasi perkalian raster untuk menghasilkan lokasi kawasan konservasi mangrove terpilih kombinasi seluruh pemangku kepentingan. Hasil analisis kesesuaian lahan menunjukkan bahwa lahan dengan kelas sesuai untuk mangrove seluas 11.564 ha $(94,8 \%$ dari luas daerah penelitian) dan sesuai marginal seluas 629 ha. Pemangku kepentingan pada tingkat lokal (kelompok mangrove, petani tambak, dan tokoh masyarakat) lebih memprioritaskan aspek sosial dibandingkan aspek fisik, pembiayaan, dan ancaman; sedangkan pemerintah daerah lebih memprioritaskan aspek pembiayaan. Dengan prioritas tersebut, lokasi kawasan konservasi mangrove paling memenuhi prioritas pemangku kepentingan (prioritas I) didapati seluas 51,7 ha; terletak di wilayah pantai Desa Babalan dan lahan tambak garam di Desa Kedungmutih, Kecamatan Wedung; sedangkan lokasi yang cukup memenuhi prioritas pemangku kepentingan (prioritas II) didapati seluas 1.626,9 ha terletak di wilayah pantai Kecamatan Wedung, Bonang, dan sebagian kecil Karangtengah.
\end{abstract}

Kata kunci: AHP; kawasan konservasi; mangrove; SIG partisipatif.

ABSTRACT Determining the location of conservation area is related to landuse planning, which involves many actors and factors. A multifactor analysis could be solved easily using Geographic Information System (GIS), but single judgment is applied. This research aimed to integrate multiactor and multifactor analysis using multicriteria analysis with participatory GIS to generate site selection mangrove conservation area. The criteria considered in the selection of mangrove conservation area consists of (i) physical aspect, (ii) social aspect, (iii) financial aspect, and (iv) threats aspect. Physical criteria was derived from land suitability analysis for mangrove; while social, financial, and threats aspect criteria were derived from population and socioeconomic data obtained from literature studies. Public participation in this site selection process were found in the weighting criteria through pairwise comparison which then analyzed with Analytical Hierarchial Process (AHP), as well as exploring local information through participatory mapping. Weighting criteria for each stakeholder then combined with spatial data through raster based analysis to found the best location that meet the priorities of stakeholdera involved. Land suitability analysis found that about 11.564 ha (94,8\% of research area) are suitable and 629 ha $(5,2 \%)$ area quite suitable for mangrove. Stakeholders in local level (mangrove conservation groups, fish farmers, and community leaders) prioritize the social aspect; while local governments prioritize financial aspect. With those priorities, the location of mangrove conservation area that best meet the priorities of stakeholders (priority I) found an area of 51,7 ha located in the coastal area of Babalan Village and salt ponds in Kedungmutih Village, Wedung Subdistrict; while the location that quite meet the priorities of stakeholders (priority II) were found covering 1626.9 ha located in coastal area of Wedung and Bonang Subdistrict, and a small portion of Karangtengah Subdistrict.

Key words: AHP; conservation areas; mangrove; Participatory GIS.

\section{PENDAHULUAN}

Kawasan konservasi merupakan kawasan yang sangat vital bagi wilayah kepesisiran. Bukan hanya karena hal ini diamanatkan oleh undang-undang ( $\underline{\mathrm{UU}}$ No. 26 tahun 2007 tentang Penataan Ruang dan UU No. 27 tahun 2007 tentang Pengelolaan Wilayah Pesisir dan Pulau-pulau Kecil), namun kawasan konservasi sangat penting guna melindungi keanekaragaman hayati dan masyarakat dari ancaman bencana alam di wilayah kepesisiran, seperti erosi pantai dan genang pasang air laut (Dahuri et al., 1996; Departemen Kelautan dan Perikanan, 2005; Nybakken, 1992; 
Ongkosongo, 2011; Peraturan Pemerintah No. 64 tahun 2010 tentang Mitigasi Bencana di Wilayah Pesisir dan Pulau-pulau Kecil).

Kebutuhan akan kawasan konservasi salah satunya sangat dirasakan pada wilayah kepesisiran Kabupaten Demak. Berdasarkan kajian yang dilakukan Dinas Kelautan dan Perikanan Provinsi Jawa Tengah pada tahun 2011, Kabupaten Demak merupakan kabupaten yang mengalami erosi pantai terluas ke-2 setelah Kabupaten Brebes, yaitu seluas 1.016,22 ha. Di Kabupaten Demak sendiri, wilayah yang mengalami erosi pantai paling besar yaitu Kecamatan Sayung (Marfai, 2012), dengan luas lahan tererosi 935,18 ha. Erosi pantai mulai terjadi di Kecamatan Sayung pada tahun 1998 (Gambar 1). Selain kenaikan muka air laut (Marfai, 2014), reklamasi pantai dan bangunan jetty pada pelabuhan Tanjung Emas diduga merupakan salah satu faktor penyebab besarnya erosi pantai di wilayah kepesisiran Kabupaten Demak (Marfai, 2012). Bangunan pelindung pantai yang pada umumnya menjorok ke laut, termasuk jetty, berpotensi mengakibatkan perubahan angin dan arus, serta menghambat aliran litoral alami, sehingga mengganggu pasokan sedimen ke pantai bagian hilir dari aliran litoral tersebut (US Army Corps of Engineers, 1984; Triatmodjo, 1999; Dahuri et al. 1996). Penelitian yang dilakukan Apriyantika (2010) dan Marfai (2012) menunjukkan bahwa terjadi kemunduran garis pantai di wilayah pantai Kecamatan Sayung.

Selain erosi pantai, wilayah kepesisiran Kabupaten Demak juga mengalami genang pasang air laut. Hingga tahun 2010, di wilayah kepesisiran Kecamatan Sayung, genang pasang air laut telah masuk ke daratan hingga sejauh $1,5 \mathrm{~km} ; 692,31$ ha pekarangan dan tambak terendam; dan 3 dusun telah hilang. Pada tahun 2012, erosi pantai juga terjadi di pesisir Kecamatan Wedung (Anonim (a), 2012). Erosi pantai dan genang pasang air laut tidak hanya merusak keanekaragaman hayati, namun juga mengancam kehidupan dan penghidupan masyarakat pesisir Kabupaten Demak.

Dalam Rencana Tata Ruang Wilayah (RTRW) Kabupaten Demak 2011 - 2031, sepanjang wilayah pantai Kabupaten Demak memang telah ditetapkan sebagai kawasan lindung (Gambar 1); baik kawasan lindung sempadan pantai, rawan bencana (erosi pantai dan gelombang pasang), maupun suaka alam (kawasan pantai berhutan bakau); dengan arahan pemanfaatan lahan utama untuk hutan mangrove. Akan tetapi, perencanaan tersebut masih bersifat umum dan belum mempertimbangkan kondisi fisik dan sosial ekonomi pada tingkat yang lebih detil dan mikro, sehingga belum terdapat pula rincian tentang bentuk pengelolaan dan/atau konservasi mangrove yang harus dilakukan serta area mana saja yang diprioritaskan.

Penentuan lokasi kawasan konservasi pada dasarnya berkaitan dengan keputusan penggunaan lahan. Keputusan penggunaan lahan sendiri merupakan suatu permasalahan yang kompleks dan seringkali kontroversial karena melibatkan banyak faktor dan banyak aktor. Banyaknya faktor berakibat pada kompleksnya analisis, namun hal ini dapat diatasi dengan pemanfaatan Sistem Informasi Geografis (SIG) yang merupakan salah satu bentuk dari sistem pendukung keputusan berbasis keruangan atau spatial decision support system/SDSS (Fauzi, 1997; Faturrohmah, 2014). Meskipun memiliki banyak keunggulan (Yeh, 2000), penggunaan SIG saja untuk penentuan penggunaan lahan dianggap masih memiliki kekurangan karena penilaian hanya berdasarkan pada penilaian tunggal dari seseorang ataupun suatu institusi, padahal keputusan penggunaan lahan melibatkan banyak aktor.
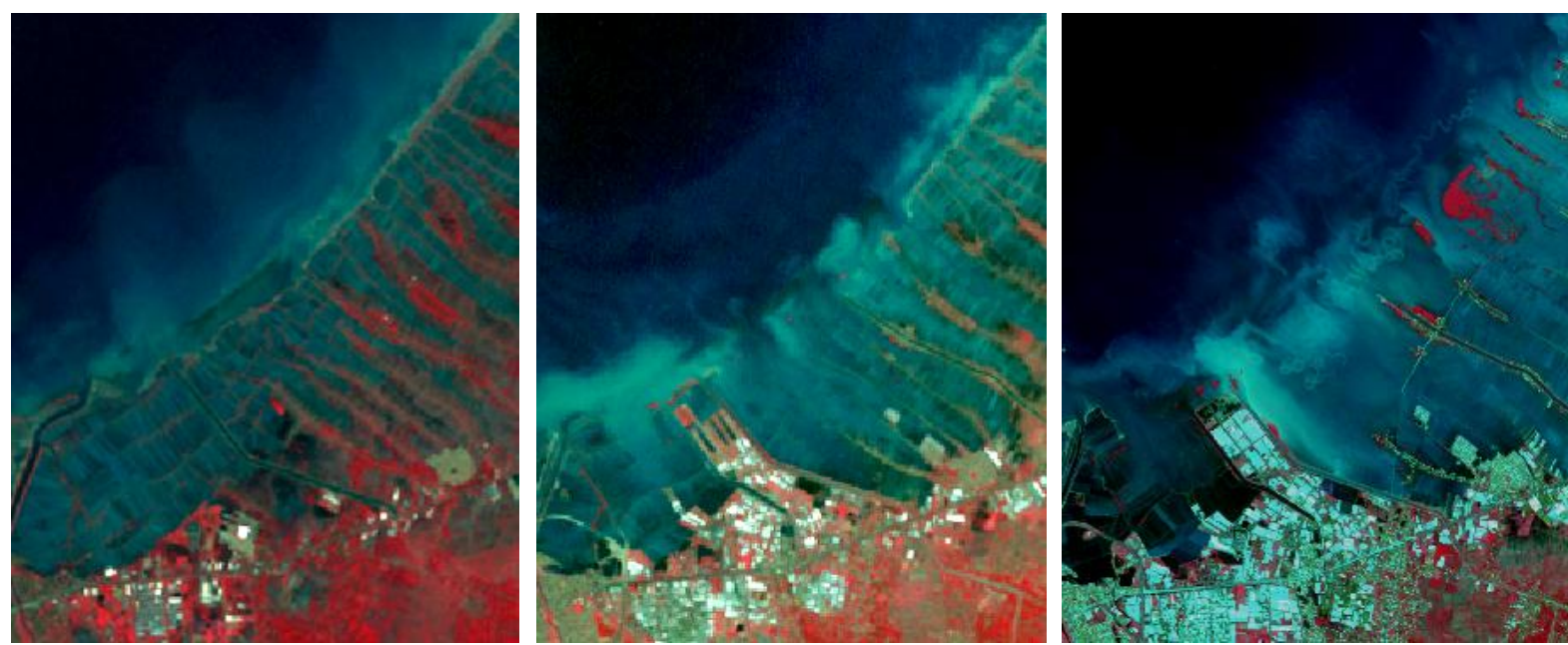

Gambar 1. Citra Satelit Wilayah Pantai Kecamatan Sayung, Kabupaten Demak (a) Landsat 1989 Komposit 432, (b) Landsat 1999 Komposit 422, dan (c) ALOS 2010 Komposit 432 


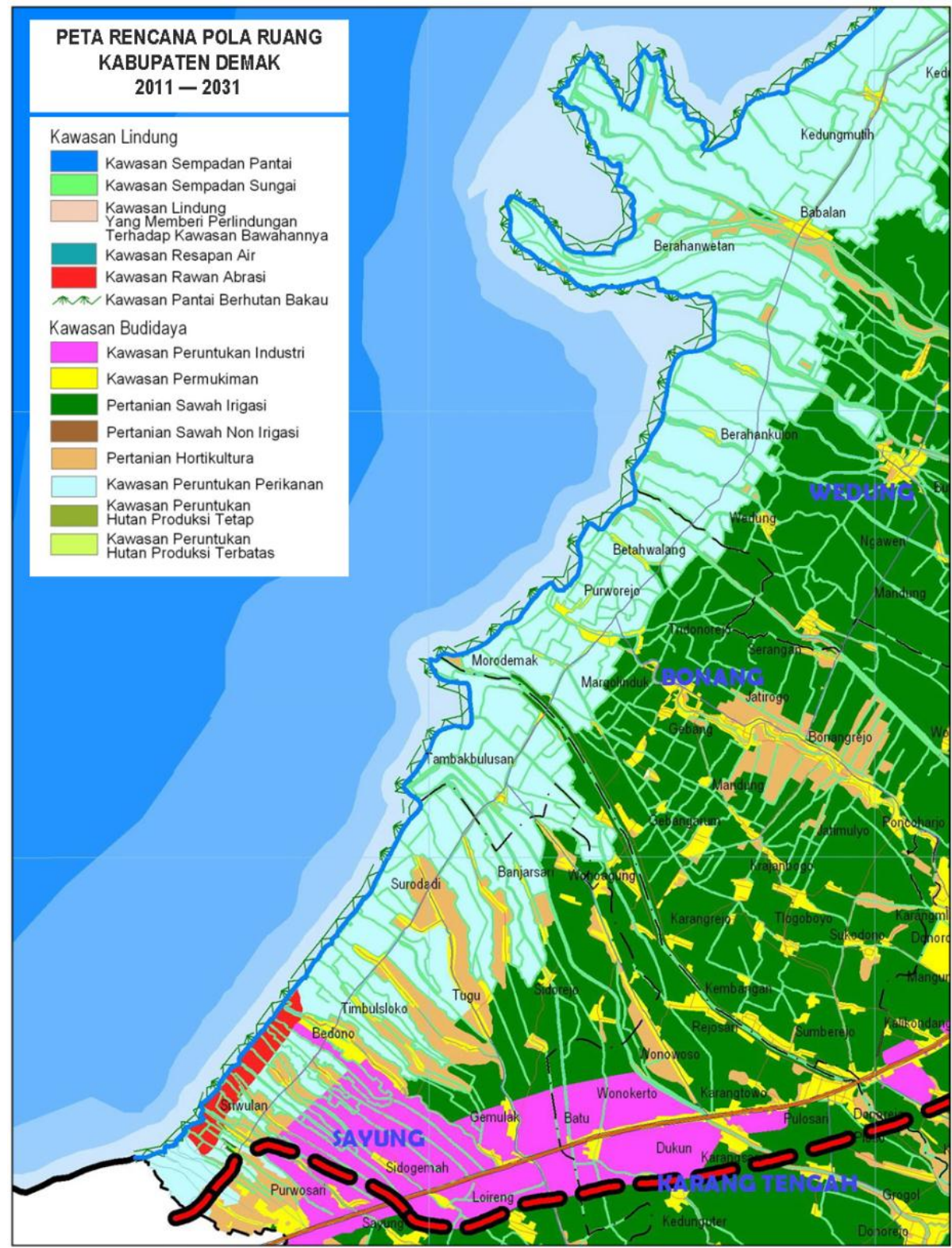

Gambar 1. Peta Pola Ruang Wilayah Kepesisiran Kabupaten Demak 2011 - 2031 Sumber: Peta Pola Ruang Kabupaten Demak 2011 - 2031

Banyaknya aktor berkonsekuensi pada beragamnya pemahaman, nilai, dan tujuan, sehingga berbeda pula keputusan penggunaan lahannya (Bordy, 2011; Feick dan Hall, 2002; Malczewski, 2006 dalam Omo-Irabor, 2011; Susskind dan Cruikshank, 1987 dalam Brody, 2006; Schmoldt et al., 2001). Sering dijumpai suatu lahan yang seharusnya diperuntukkan sebagai kawasan konservasi, namun dimanfaatkan sebagai lahan budidaya, baik karena kesengajaan maupun ketidaktahuan dari para pemangku kepentingan di dalamnya. Karenanya, penentuan penggunaan lahan tidak hanya membutuhkan pengetahuan, keahlian, dan data; namun juga harus memperhitungkan pendapat para pemangku kepentingan (Feick dan Hall, 2002; Kristanty, 2013; Schmoldt et al., 2001).

Salah satu metode yang dapat mengintegrasikan multifaktor dan multiaktor dalam pengambilan keputusan adalah analisis multikriteria dengan Analytical Hierarchial Process (AHP). Dengan AHP, dimungkinkan untuk melakukan pemodelan pemilihan lokasi dengan pembobotan kriteria yang bervariasi, bergantung pada prioritas setiap pemangku kepentingan yang terlibat (Hapsari, 2013; Hidayat, 2013; Zarkesh, 2005). Dalam penelitian ini, bobot kriteria ditentukan oleh kelompok mangrove, petani tambak, perwakilan tokoh masyarakat, dan pemerintah daerah -bukan berdasarkan penilaian peneliti ataupun regulasi-, sehingga dapat diketahui Prioritas para pemangku kepentingan tersebut dalam pemilihan kawasan konservasi mangrove. Dengan demikian, pemanfaatan AHP dalam penelitian ini merupakan salah satu bentuk participatory GIS dan dengan mengadopsi Prioritas para pemangku kepentingan tersebut, diharapkan dapat terpilih lokasi kawasan http://jurnal.ugm.ac.id/mgi | 151 
konservasi mangrove dengan potensi konflik kecil (Brody, 2006; Feick dan Hall, 2002; Omo-Irabor, 2011).

Selain dalam pembobotan kriteria, masyarakat juga dilibatkan dalam penggalian informasi dinamika perubahan lingkungan yang terjadi dari waktu ke waktu yang terekam dalam ingatan masyarakat dalam bentuk pengetahuan lokal. Pengetahuan lokal ini dapat digali dan ditransformasi menjadi data spasial melalui pemetaan partisipatif untuk membantu meningkatkan kualitas perencanaan (Abbot et al. 1998; IFAD, 2009; McCall dan Minang, 2006; Nirwansyah, 2012; Suskind et al., 2000 dalam Kay dan Alder, 2005). Penggabungan participatory GIS dan expert system GIS merupakan kombinasi yang baik untuk membangun SDSS berbasis masyarakat guna memilih lokasi kawasan konservasi mangrove dengan meminimalkan potensi konflik pengelolaan kawasan.

\section{METODE PENELITIAN}

Mangrove tumbuh pada wilayah yang masih dipengaruhi oleh pasang surut air laut, yang dalam terminologi wilayah kepesisiran disebut sebagai wilayah pantai. Pada penelitian ini dikaji pula aspek sosial dan kependudukan, dengan unit data berupa wilayah administrasi. Karena terdapat dua unit data yang berbeda, yaitu unit lahan dan unit wilayah administratif, maka digunakanlah desa pantai sebagai daerah penelitian pada penelitian ini.

Definisi desa pantai yang cukup populer adalah definisi desa pantai menurut BPS, yang mengartikan desa pantai sebagai desa yang memiliki garis pantai atau berbatasan langsung dengan laut. Namun, dengan definisi tersebut, beberapa wilayah yang potensial untuk pertumbuhan mangrove akan terabaikan (tidak diperhitungkan) karena genang pasang air laut -yang merupakan salah satu indikator lahan potensial untuk pertumbuhan mangrove- melimpas hingga ke desadesa yang tidak memiliki garis pantai. Dengan demikian, desa pantai yang dimaksud dalam penelitian ini adalah desa-desa di Kabupaten Demak yang masih terkena oleh genang pasang air laut (Tabel 1).

Kriteria yang diperhitungkan dalam pemilihan lokasi kawasan konservasi mangrove pada penelitian ini yaitu (i) aspek fisik lahan, (ii) aspek sosial, (iii) aspek pembiayaan, dan (iv) aspek ancaman (Tabel 2). Aspek fisik merepresentasikan kemampuan lahan untuk menopang pertumbuhan mangrove, didekati dengan analisis kesesuaian lahan. Aspek sosial merepresentasikan penerimaan masyarakat terhadap pengembangan kawasan konservasi mangrove, didekati dengan mengkaji kepemilikan lahan dan kebergantungan pada lahan. Aspek pembiayaan merepresentasikan besar/kecilnya biaya yang mungkin diperlukan secara relatif terhadap lahan-lahan yang ada di wilayah kajian terdiri dari pembebasan lahan dan rekayasa teknis. Sedangkan aspek ancaman merepresentasikan hal-hal yang berpotensi menghambat pertumbuhan mangrove, baik ancaman dari sisi fisik maupun sosial; yang didekati dari tinggi gelombang, kebergantungan pada lahan, dan tingkat kemiskinan.

Tabel 1. Desa-desa di Kabupaten Demak yang terkena genang pasang air laut

\begin{tabular}{llcllc}
\hline & Desa & Luas $\left(\mathrm{km}^{2}\right)^{*}$ & No & Desa & Luas $^{*}\left(\mathrm{~km}^{2}\right)^{*}$ \\
\hline Kecamatan & Sayung & 56,80 & 14 & Gebang & 4,56 \\
1 & Banjarsari & 5,40 & 15 & Margolinduk & 1,20 \\
2 & Bedono & 7,61 & 16 & Morodemak & 4,04 \\
3 & Gemulak & 4,06 & 17 & Purworejo & 7,00 \\
4 & Purwosari & 4,31 & 18 & Tridonorejo & 5,08 \\
5 & Sidogemah & 6,61 & Kecamatan Wedung & 83,56 \\
6 & Sidorejo & 8,44 & 19 & Babalan & 7,86 \\
7 & Sriwulan & 4,30 & 20 & Berahan Kulon & 18,27 \\
8 & Surodadi & 6,55 & 21 & Berahan Wetan & 12,77 \\
9 & Timbulsloko & 6,18 & 22 & Bungo & 14,73 \\
10 & Tugu & 3,34 & 23 & Kedungkarang & 3,34 \\
Kecamatan & Karangtengah & 11,60 & 24 & Kedungmutih & 3,55 \\
11 & Tambakbulusan & 7,43 & 25 & Kendalasem & 2,37 \\
12 & Wonoagung & 4,17 & 26 & Mutih Kulon & 7,61 \\
Kecamatan & Bonang & 26,46 & 27 & Wedung & 13,06 \\
13 & Betahwalang & \multicolumn{2}{c}{4,58} & & 178,42 \\
\hline
\end{tabular}

Sumber: Arifin (2012) 
Tabel 2. Kebutuhan Data dan Variabel Penelitian

\begin{tabular}{|c|c|c|c|}
\hline Tujuan & Kebutuhan Data & Variabel Penelitian & Sumber Data \\
\hline \multirow{10}{*}{$\begin{array}{l}\text { Tujuan 1: } \\
\text { Menganalisis kesesuaian } \\
\text { lahan secara fisik untuk } \\
\text { mangrove }\end{array}$} & Karakteristik fisik lahan yang & 1) Salinitas (\%o) & 1) Uji laboratorium sampel air \\
\hline & terkait dengan persyaratan & 2) Kadar bahan organiK (\%) & 2) Uji laboratorium sampel tanah \\
\hline & tumbuh mangrove & 3) Suhu perairan $\left({ }^{\circ} \mathrm{C}\right)$ & 3) Pengukuran dengan alat \\
\hline & & $\begin{array}{l}\text { 4) Kadar bahan tersuspensi } \\
(\mathrm{mg} / \mathrm{L})\end{array}$ & 4) Pengukuran dengan alat \\
\hline & & 5) Derajat keasaman perairan & 5) Pengukuran dengan alat \\
\hline & & 6) Kadar oksigen terlarut (ppm) & 6) Pengukuran dengan alat \\
\hline & & 7) Tekstur tanah & 7) Sidik cepat di lapangan \\
\hline & & 8) Derajat keasaman tanah & 8) Uji laboratorium sampel tanah \\
\hline & & 9) Kisaran pasang surut (m) & 9) Informasi dari masyarakat \\
\hline & & 10) Curah hujan & 10) BPDAS Pemali Jratun \\
\hline \multirow[b]{2}{*}{$\begin{array}{l}\text { Tujuan 2: } \\
\text { Mengkaji Prioritas para } \\
\text { pemangku kepentingan } \\
\text { dalam pemilihan lokasi } \\
\text { kawasan konservasi } \\
\text { mangrove }\end{array}$} & Faktor-faktor yang & Perbandingan kriteria secara & Wawancara \\
\hline & $\begin{array}{l}\text { dipertimbangkan pemangku } \\
\text { kepentingan dalam pemilihan } \\
\text { lahan untuk kawasan } \\
\text { konservasi mangrove, yang } \\
\text { terdiri atas aspek fisik, sosial, } \\
\text { ekonomi, dan ancaman }\end{array}$ & berpasangan & \\
\hline $\begin{array}{l}\text { Tujuan 3: } \\
\text { Memilih lokasi kawasan } \\
\text { konservasi mangrove } \\
\text { dengan mengadopsi }\end{array}$ & $\begin{array}{l}\text { 1) Aspek fisik (kesesuaian lahan } \\
\text { secara fisik untuk pertumbuhan } \\
\text { mangrove) }\end{array}$ & $\begin{array}{l}\text { 1) Kelas kesesuaian lahan untuk } \\
\text { pertumbuhan mangrove } \\
\text { (Sesuai, sesuai marginal, tidak } \\
\text { sesuai) }\end{array}$ & $\begin{array}{l}\text { Peta kesesuaian lahan secara fisik } \\
\text { untuk pertumbuhan mangrove }\end{array}$ \\
\hline \multirow{6}{*}{$\begin{array}{l}\text { Prioritas para pemangku } \\
\text { kepentingan }\end{array}$} & 2) Aspek sosial (kepemilikan & 1) Kepemilikan lahan (tanah & 1) Badan Pertanahan Nasional \\
\hline & lahan) & $\begin{array}{l}\text { 2) Jumlah penduduk dengan } \\
\text { mata pencaharian sektor primer }\end{array}$ & 2) BKKBN Kabupaten Demak \\
\hline & $\begin{array}{l}\text { 3) Aspek ekonomi (pembebasan } \\
\text { lahan, rekayasa teknis) }\end{array}$ & $\begin{array}{l}\text { 1) Kepemilikan lahan (tanah } \\
\text { negara, tanah hak milik) } \\
\text { 2) Tinggi gelombang (m) }\end{array}$ & $\begin{array}{l}\text { 1) Badan Pertanahan Nasional } \\
\text { dan informasi kepala desa } \\
\text { 2) Pengukuran di lapangan }\end{array}$ \\
\hline & 4) Aspek ancaman (tinggi & 1) Tinggi gelombang (m) & 1) Pengukuran di lapangan \\
\hline & $\begin{array}{l}\text { gelombang, kebergantungan } \\
\text { pada lahan, tingkat kemiskinan) }\end{array}$ & $\begin{array}{l}\text { 2) Jumlah penduduk dengan } \\
\text { mata pencaharian pada sektor } \\
\text { primer }\end{array}$ & 2) Kecamatan Dalam Angka \\
\hline & & $\begin{array}{l}\text { 3) Jumlah keluarga pra } \\
\text { sejahtera dan keluaraga } \\
\text { sejahtera I }\end{array}$ & 3) BKKBN Kabupaten Demak \\
\hline
\end{tabular}

Populasi pada penelitian ini adalah keseluruhan lahan di desa pantai di Kabupaten Demak. Lahan tersebut dinilai dari beberapa aspek, yaitu aspek fisik, sosial, ekonomi, dan ancaman. Penilaian lahan dari aspek sosial, ekonomi, dan ancaman dinilai secara keseluruhan karena data yang digunakan merupakan data sekunder; sedangkan penilaian untuk aspek fisik diperoleh dari data primer mengenai karakteristik air dan tanah.

Pengambilan sampel air dan tanah/sedimen dilakukan berdasarkan satuan lahan, yang diperoleh dari hasil tumpangsusun antara satuan-satuan bentuklahan, penggunaan lahan, dan elevasi lahan. Bentuklahan yang diperhitungkan dalam penelitian ini dibatasi pada bentuklahan asal proses marin, hal ini berdasarkan penelitian Yuniastuti (2013) yang menyatakan bahwa bentuklahan yang sesuai untuk mangrove adalah bentuklahan asal proses marin. Terdapat 36 satuan lahan pada daerah penelitian.

Tinggi gelombang digunakan sebagai variabel yang dianggap dapat merepresentasi kekuatan gelombang secara relatif di wilayah pantai Kabupaten Demak. Pengukuran tinggi gelombang dilakukan pada 6 lokasi (Gambar 2) yang dapat merepresentasikan variasi tinggi gelombang di wilayah pantai Kabupaten Demak. Dengan adanya proses erosi dan akreasi, maka pengukuran tinggi gelombang dilakukan pada tepi pantai yang mengalami erosi pantai (diidentifikasi dari mundurnya garis pantai, diwakili 2 titik pengukuran), tepi pantai yang mengalami akresi (diidentifikasi dari majunya garis pantai), dan tepi pantai yang cenderung stabil (diidentifikasi dari kecil atau tidak adanya perubahan garis pantai).

Pemilihan lokasi dilakukan dengan operasi aritmatik dan tumpangsusun raster antar peta aspek. 
Masing-masing aspek sendiri tersusun oleh variabelvariabel yang berbeda satuan. Agar dapat dianalisis bersama, maka nilai variabel distandardisasi dengan menggunakan persamaan (1). Standardisasi akan menghasilkan nilai baru dengan nilai terkecil (paling tidak mendukung/tidak berkontribusi positif untuk pengembangan kawasan konservasi mangrove) yaitu 0 dan nilai terbesar (paling mendukung/berkontribusi positif untuk pengembangan kawasan konservasi mangrove) yaitu 1. Persamaan (1) hanya berlaku untuk data interval dan rasio. Untuk data nominal, standardisasi dilakukan dengan pertimbangan tertentu. Rincian selengkapnya tentang standardisasi data untuk penyusunan peta aspek tersaji pada Tabel 4 .
Keterangan:

$X_{2} \quad$ : Nilai variabel $X$ hasil standardisasi

$X_{1} \quad$ : Nilai variabel $X$ yang akan distandardisasi

$X_{\min }$ : Nilai variabel $X$ terkecil

$X_{\max }$ : Nilai variabel $\mathrm{X}$ terbesar

Keempat peta aspek selanjutnya disintesis dengan operasi aritmatik raster dengan mengalikan nilai cell per aspek/kriteria dengan bobot kriteria. Dari operasi ini diperoleh peta lokasi kawasan konservasi mangrove terpilih berdasarkan Prioritas masing-masing pemangku kepentingan, yang dikategorikan menjadi 5 kelas (Tabel 5) dengan metode klasifikasi equal interval.

$$
X_{2}=\frac{\left(X_{1}-X_{\min }\right)}{\left(X_{\max }-X_{\min }\right)}
$$

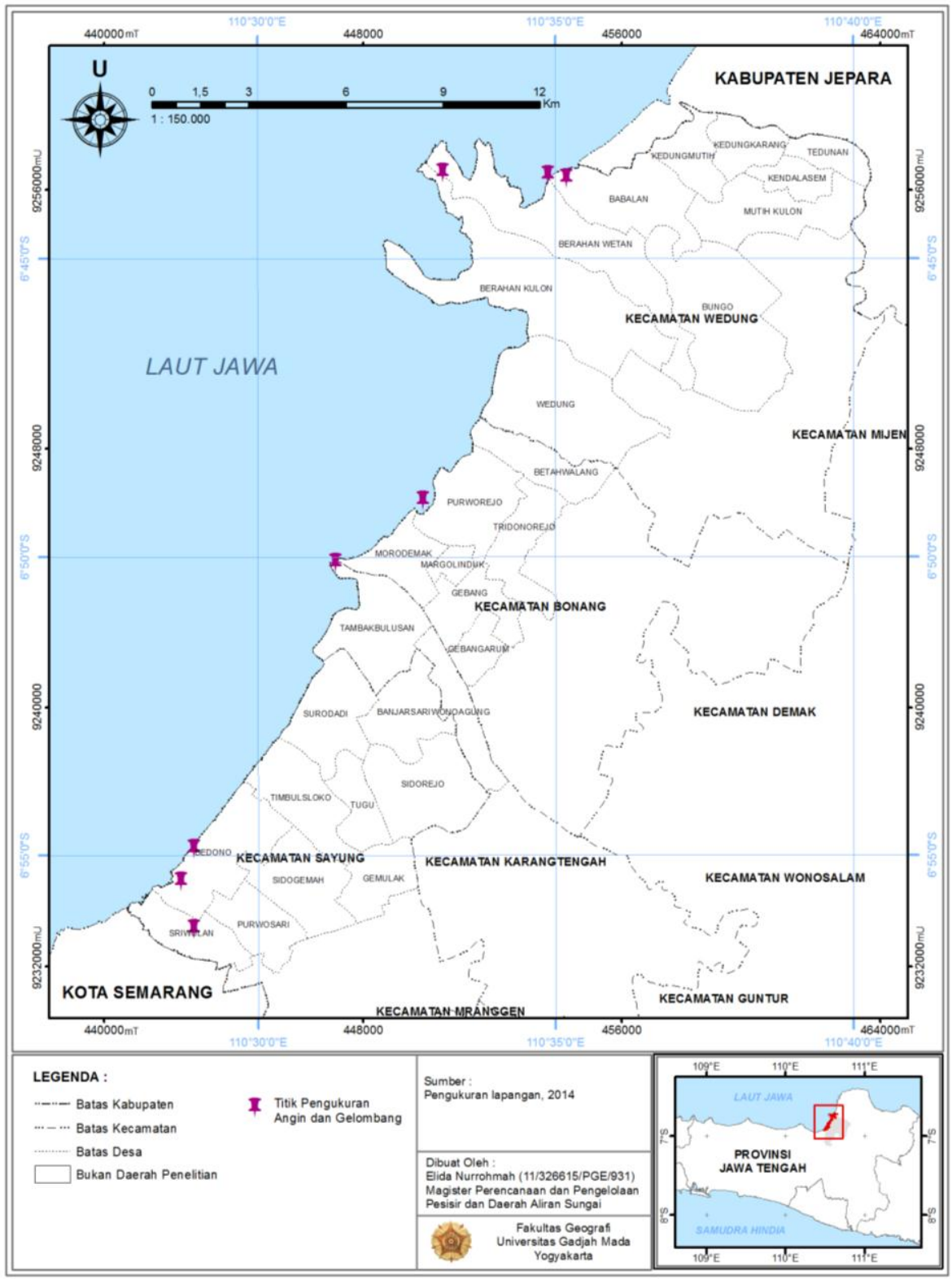

Gambar 2. Lokasi Pengukuran Tinggi Gelombang 
Tabel 3. Rincian Informan Kunci

\begin{tabular}{|c|c|c|}
\hline Informan Kunci & Peran & Informasi yang Ingin Digali \\
\hline Kelompok mangrove & $\begin{array}{l}\text { 1) Sebagai kelompok pro konservasi } \\
\text { mangrove } \\
\text { 2) Sebagai kelompok yang mengetahui } \\
\text { perkembangan mangrove (kerusakan dan } \\
\text { rehabilitasi) }\end{array}$ & $\begin{array}{l}\text { 1) Riwayat serangan hama dan ternak terhadap } \\
\text { mangrove } \\
\text { 2) Permasalahan/tantangan pengembangan } \\
\text { kawasan konservasi mangrove } \\
\text { 3) Partisipasi masyarakat dalam konservasi } \\
\text { mangrove } \\
\text { 4)Pembobotan kriteria untuk pemilihan lahan } \\
\text { untuk konservasi mangrove }\end{array}$ \\
\hline Pemerintah daerah & 1) Sebagai lembaga yang memiliki & 1) Riwayat kerusakan/ kematian mangrove \\
\hline (direpresentasikan oleh & kewenanganmenyusun RTRW & 2) Arahan pengembangan wilayah pesisir \\
\hline BAPPEDA, Dinas Kelautan dan & (BAPPEDA) & Kabupaten Demak \\
\hline Perikanan, dan Dinas Pertanian & 2) Sebagai lembaga yang memiliki & 3) Permasalahan/tantangan pengembangan \\
\hline Kabupaten Demak) & $\begin{array}{l}\text { kewenangan menyusun zonasi wilayah } \\
\text { pesisir } \\
\text { 3) Sebagai pengambil kebijakan } \\
\text { pengelolaan wilayah pesisir }\end{array}$ & $\begin{array}{l}\text { kawasan konservasi mangrove } \\
\text { 4) Pembobotan kriteria untuk pemilihan lahan } \\
\text { untuk konservasi mangrove }\end{array}$ \\
\hline $\begin{array}{l}\text { Petani tambak } \\
\text { Tokoh } \\
\text { Masyarakat }\end{array}$ & $\begin{array}{l}\text { Sebagai kelompok penggunan wilayah } \\
\text { pantai }\end{array}$ & $\begin{array}{l}\text { 1) Riwayat serangan hama dan ternak terhadap } \\
\text { mangrove } \\
\text { 2) Permasalahan/tantangan pengembangan } \\
\text { kawasan konservasi mangrove } \\
\text { 3) Partisipasi masyarakat dalam konservasi } \\
\text { mangrove } \\
\text { 4) Pembobotan kriteria untuk pemilihan lahan } \\
\text { untuk konservasi mangrove }\end{array}$ \\
\hline
\end{tabular}

Tabel 4. Penyusunan Peta Aspek untuk Pemilihan Lokasi Kawasan Konservasi Mangrove

\begin{tabular}{ccc}
\hline Sumber Data & Jenis dan & Jenis \& Kategori Data \\
Kategori Data & Olah Data & Hasil Standardisasi \\
\hline
\end{tabular}

Peta Aspek Fisik

Peta kesesuaian lahan untuk mangrove

Peta Aspek Sosial

1.Persentase jumlah penduduk dengan mata pencaharian di sektor primer per desa $(\% \mathrm{P})$

2.Kepemilikan lahan

Peta Aspek Pembiayaan

1.Kepemilikan lahan

2.Tinggi gelombang
Data ordinal dengan kelas kesesuaian lahan: sesuai, sesuai marginal, tidak sesuai

Standardisasi nilai kesesuaian lahan untuk mangrove

1. Data rasio

2. Data nominal

1. Standardisasi nilai persentase jumlah penduduk dengan mata pencaharian di sektor primer

2. Standardisasi nilai kepemilikan lahan

3. Standardisasi nilai aspek sosial

1.Data nominal

2.Data rasio

1.Standardisasi nilai kepemilikan lahan

2.Standardisasi nilai tinggi gelombang

3.Standardisasi nilai aspek pembiayaan
Data rasio dengan ketentuan: sesuai $=1$ sesuai marginal $=0$ tidak sesuai $=$ tidak diikutsertakan dalam pemilihan lokasi kawasan konservasi mangrove

Data rasio dengan ketentuan

1. nilai $\% \mathrm{P}$ terkecil bernilai 1 dan \%P terbesar bernilai 0

2. lahan dengan hak milik $=0$ dan lahan milik negara $=1$

3. nilai standardisasi aspek sosial diperoleh dari menjumlahkan nilai standardisasi $\% \mathrm{P}$ dan kepemilikan lahan, kemudian distandardisasi

Data rasio dengan ketentuan:

1.lahan dengan hak milik $=0$ dan lahan milik negara $=1$

2.tinggi gelombang terkecil bernilai 1 dan tinggi gelombang terbesar bernilai 0

3.nilai standardisasi aspek pembiayaan diperoleh dari menjumlahkan nilai standardisasi 
Lanjutan Tabel 4.

\begin{tabular}{|c|c|c|c|}
\hline Sumber Data & $\begin{array}{r}\text { Jenis dan } \\
\text { Kategori Data }\end{array}$ & Olah Data & $\begin{array}{l}\text { Jenis \& Kategori Data } \\
\text { Hasil Standardisasi }\end{array}$ \\
\hline Peta Aspek Pembiayaan & & & $\begin{array}{l}\text { standardisasi kepemilikan lahan } \\
\text { dan tinggi gelombang, kemudian } \\
\text { distandardisasi }\end{array}$ \\
\hline $\begin{array}{l}\text { Peta Aspek Ancaman } \\
\text { 1.Persentase jumlah } \\
\text { penduduk dengan mata } \\
\text { pencaharian di sektor } \\
\text { primer per desa (\%P) } \\
\text { 2.Persentase jumlah } \\
\text { keluarga dengan kategori } \\
\text { keluarga pra sejahtera } \\
\text { dan keluarga sejahtera I } \\
\text { (\%KPS) } \\
\text { 3. Tinggi gelombang }\end{array}$ & $\begin{array}{l}\text { 1. Data rasio } \\
\text { 2. Data rasio } \\
\text { 3. Data rasio }\end{array}$ & $\begin{array}{l}\text { 1. Standardisasi nilai persentase } \\
\text { jumlah penduduk dengan mata } \\
\text { pencaharian di sektor primer } \\
\text { 2. Standardisasi nilai persentase } \\
\text { jumlah keluarga dengan } \\
\text { kategori keluarga pra sejahtera } \\
\text { dan keluarga sejahtera I } \\
\text { 3. Standardisasi nilai tinggi } \\
\text { gelombang }\end{array}$ & $\begin{array}{l}\text { Data rasio dengan ketentuan } \\
\text { 1.nilai \%P terkecil bernilai } 1 \text { dan \%P } \\
\text { terbesar bernilai } 0 \\
\text { 2.nilai \%KPS terkecil bernilai } 1 \text { dan } \\
\% \text { KPS terbesar bernilai } 0 \\
\text { 3.nilai tinggi gelombang terkecil } \\
\text { bernilai } 1 \text { dan tinggi gelombang } \\
\text { terbesar bernilai } 0 \\
\text { 4.nilai standardisasi aspek sosial, } \\
\text { yang diperoleh dari : penjumlahan } \\
\text { nilai standardisasi \%P, \%KPS, dan } \\
\text { tinggi gelombang, kemudian } \\
\text { distandardisasi }\end{array}$ \\
\hline
\end{tabular}

Tabel 5. Kategorisasi Prioritas Lahan Terpilih Menurut Prioritas Pemangku Kepentingan

\begin{tabular}{lll}
\hline \multicolumn{1}{c}{ Kategori } & \multicolumn{1}{c}{ Nilai $^{*}$} & \multicolumn{1}{c}{ Keterangan } \\
\hline Prioritas I & $0,81-1$ & Lahan yang paling diinginkan untuk dijadikan kawasan konservasi mangrove \\
Prioritas II & $0,61-0,8$ & Lahan yang diinginkan untuk dijadikan kawasan konservasi mangrove \\
Prioritas III & $0,41-0,6$ & Lahan yang cukup diinginkan untuk dijadikan kawasan konservasi mangrove \\
Prioritas IV & $0,21-0,4$ & Lahan yang tidak diinginkan untuk dijadikan kawasan konservasi mangrove \\
Prioritas V & $0-0,2$ & Lahan yang paling tidak diinginkan untuk dijadikan kawasan konservasi mangrove \\
\hline
\end{tabular}

${ }^{\star}$ Hasil perkalian nilai cell dengan bobot kriteria. Dilakukan pada keempat kriteria. Penjumlahan keempat hasil perkalian menghasilkan nilai tertinggi 1 dan nilai terendah 0 .

\section{HASIL DAN PEMBAHASAN}

\section{Kesesuaian Lahan Secara Fisik untuk Mangrove}

Penilaian kesesuaian lahan secara fisik untuk suatu peruntukan penting untuk dilakukan karena setiap lahan memiliki karakteristik yang spesifik dan karenanya memiliki kemampuan yang berbeda-beda untuk menopang aktivitas budidaya dan pembangunan. Hasil analisis kesesuaian lahan dengan metode FAO (Hardjowigeno dan Widiatmaka, 2011) menunjukkan bahwa tidak ada lahan di wilayah kajian yang sesuai untuk mangrove. Hal ini dikarenakan dalam metode FAO, kelas kesesuaian lahan ditentukan berdasarkan kualitas lahan terburuk. Dalam penelitian ini, variabel yang menyebabkan tidak adanya lahan terkategori sesuai adalah suhu perairan dan kadar bahan tersuspensi. Mengingat kedua variabel tersebut bukanlah parameter utama bagi pertumbuhan mangrove, peneliti melakukan modifikasi dalam pengkategorian kelas kesesuaian lahan dengan ketentuan seperti tercantum pada Tabel 6 .

Dengan modifikasi yang dilakukan, diperoleh dua kelas kesesuaian lahan pada wilayah kajian, yaitu kelas sesuai dan sesuai marginal (Gambar 3). Lahan dengan kelas sesuai didapatkan seluas 11.564 ha $(94,8 \%$ dari luas wilayah kajian) dan sesuai marginal seluas 629 ha (5,2 \%). Menurut bentuklahannya, lahan dengan kelas sesuai terdapat pada bentuklahan dataran delta, rataan lumpur, dan dataran alluvial pantai (Tabel 7). Lahan yang berupa dataran delta seluruhnya termasuk pada kategori sesuai, sedangkan bentuklahan rataan lumpur dan dataran alluvial pantai sebagian termasuk kategori sesuai dan sebagian lagi sesuai marginal dikarenakan faktor penggunaan lahan (Tabel 8 dan 9).

Pada bentuklahan rataan lumpur, kelas sesuai terdapat pada penggunaan lahan tambak ikan/udang, tambak garam, tubuh air, permukiman, dan sawah. Penggunaan lahan tambak ikan/udang pada umumnya memang sesuai untuk mangrove karena secara periodik tambak digenangi air pasang. Permukiman dan sawah sendiri pada umumnya tidak sesuai untuk mangrove, namun karena genang pasang air laut telah masuk cukup jauh ke arah daratan, beberapa areal permukiman dan sawah tergenang oleh genang pasang air laut sehingga areal tersebut sesuai untuk petumbuhan mangrove. Permukiman dan sawah yang termasuk pada kelas sesuai ini berlokasi di sepanjang Sungai Tuntang ke arah Pelabuhan Perikanan Pantai (PPP) Morodemak dan areal persawahan di tepi Sungai 
Wulan di Desa Bungo. Penggunaan lahan berupa areal mangrove justru masuk pada kelas sesuai marginal karena rendahnya nilai salinitas pada saat pengukuran sebesar 2,7 \%o. Melihat pada lokasinya, tutupan lahan mangrove yang nilai salinitasnya rendah ini terdapat di beberapa lokasi di tepi pantai dan tepi sungai. Maka, rendahnya nilai salinitas ini kemungkinan dikarenakan pasokan air tawar dari aliran sungai.

Tabel 6. Kategori Kesesuaian Lahan untuk Mangrove

\begin{tabular}{llc}
\hline \multicolumn{1}{c}{ Kategori } & \multicolumn{1}{c}{ Keterangan } & Skor \\
\hline Sangat sesuai & Semua parameter menunjukkan kategori sesuai & 4 \\
Sesuai & Semua parameter utama menunjukkan kategori sesuai & 3 \\
Sesuai marginal & Salah sat parameter utama menunjukkan kategori tidak / kurang sesuai & 2 \\
Tidak sesuai & Seluruh parameter menunjukkan kategori tidak sesuai & 1 \\
\hline
\end{tabular}

* Parameter utama : salinitas, tekstur tanah

Tabel 7. Luas Kelas Kesesuaian Lahan Dirinci Menurut Bentuklahan

\begin{tabular}{cccc}
\hline & Luas menurut Bentuklahan (ha) & & \\
Dataran aluvial pantai & Dataran delta & Rataan lumpur & TOTAL \\
\hline $5,304.42$ & $1,239.70$ & $5,019.99$ & $11,564.11$ \\
586.27 & & 42.71 & 628.98 \\
$5,890.69$ & $1,239.70$ & $5,062.70$ & $12,193.10$ \\
\hline
\end{tabular}

Sumber : Analisis Kesesuaian Lahan (2014)

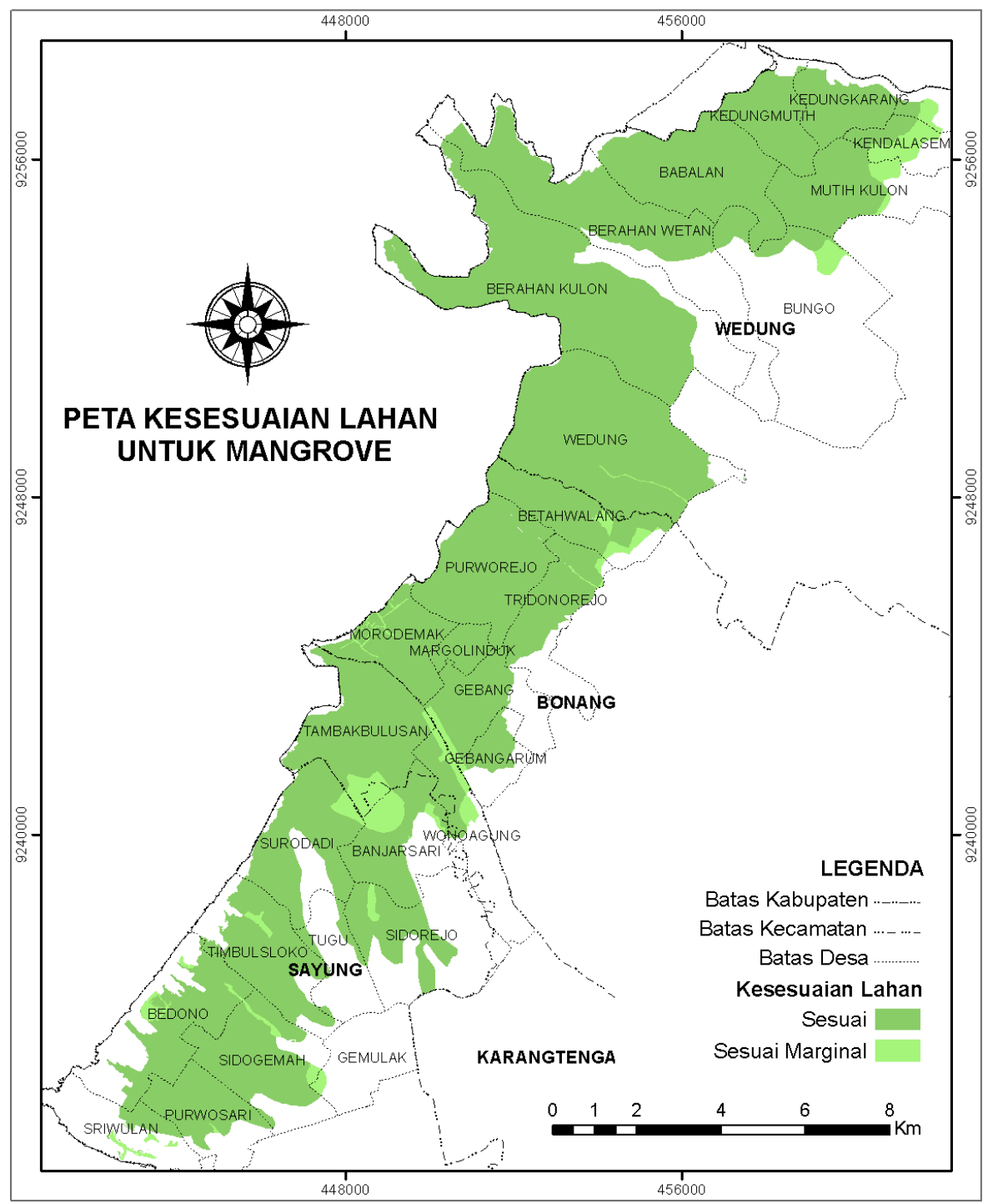

Gambar 3. Peta Kesesuaian Lahan Secara Fisik untuk Mangrove 
Tabel 8. Luas Kelas Kesesuaian Lahan Dirinci Menurut Penggunaan Lahan

\begin{tabular}{lcccccccc}
\hline \multicolumn{1}{c}{ Kelas } & & \multicolumn{9}{c}{ Luas menurut Penggunaan Lahan (ha) } \\
Kesesuaian Lahan & Kebun Campur & Mangrove & Permukiman & Sawah & Tambak & Tambak Garam & Tubuh Air & TOTAL \\
\hline Sesuai & & 40.07 & 96.15 & 110.88 & $10,100.90$ & $1,080.55$ & 135.56 & $11,564.11$ \\
Sesuai Marginal & 61.44 & 42.71 & 91.83 & 228.29 & 204.71 & & 628.98 \\
$\quad$ TOTAL & 61.44 & 82.79 & 187.98 & 339.18 & $10,305.61$ & $1,080.55$ & 135.56 & $12,193.10$ \\
\hline
\end{tabular}

Sumber : Analisis Kesesuaian Lahan (2014)

Tabel 9. Luas Kelas Kesesuaian Lahan Dirinci Menurut Bentuklahan dan Penggunaan Lahan

\begin{tabular}{|c|c|c|c|c|c|c|c|c|}
\hline \multirow{2}{*}{$\begin{array}{c}\text { Kelas } \\
\text { Kesesuaian Lahan }\end{array}$} & \multicolumn{8}{|c|}{ Luas menurut Penggunaan Lahan (ha) } \\
\hline & Kebun Campur & Mangrove & Permukiman & Sawah & Tambak & Tambak Garam & Tubuh Air & TOTAL \\
\hline Sesuai & & 40.07 & 96.15 & 110.88 & $10,100.9$ & $1,080.55$ & 135.56 & $11,564.1$ \\
\hline Dataran alluvial par & & & 13.24 & & $4,843.38$ & 421.39 & 26.41 & $5,304.42$ \\
\hline Dataran delta & & 40.07 & & & $1,131.31$ & & 68.32 & $1,239.70$ \\
\hline Rataan lumpur & & & 82.91 & 110.88 & $4,126.20$ & 659.16 & 40.83 & $5,019.99$ \\
\hline Sesuai Marginal & 61.44 & 42.71 & 91.83 & 228.29 & 204.71 & & & 628.98 \\
\hline $\begin{array}{l}\text { Dataran alluvial } \\
\text { pantai }\end{array}$ & 61.44 & & 91.83 & 228.29 & 204.71 & & & 586.27 \\
\hline Rataan lumpur & & 42.71 & & & & & & 42.71 \\
\hline TOTAL & 61.44 & 82.79 & 187.98 & 339.18 & $10,305.6$ & $1,080.55$ & 135.56 & $12,193.1$ \\
\hline
\end{tabular}

Sumber : Analisis Kesesuaian Lahan (2014)

Seperti halnya dengan bentuklahan rataan lumpur, pada bentuklahan dataran aluvial pantai, kelas sesuai terdapat pada penggunaan lahan tambak ikan/udang, tambak garam, tubuh air, dan permukiman; sedangkan kelas sesuai marginal terdapat pada penggunaan lahan kebun campur, sawah, serta permukiman dan tambak ikan/udang. Penggunaan lahan kebun campur, sawah, dan permukiman pada umumnya memang termasuk pada kelas sesuai marginal karena tekstur tanah yang sedang dan salinitas yang rendah. Sebaliknya, terdapat pula permukiman yang secara periodik tergenang pasang air laut (pada umumnya permukiman di tepi sungai) sehingga lingkungannya menjadi sesuai untuk pertumbuhan mangrove, seperti halnya tambak ikan/udang, tambak garam, dan tubuh air (sungai).

\section{Prioritas Pemangku Kepentingan dalam Pemilihan Lokasi Kawasan Konservasi Mangrove}

Prioritas pemangku kepentingan mencerminkan pemikiran, cara pandang, dan sikap pemangku kepentingan dalam memanfaatkan suatu lahan. Hal ini penting untuk dikaji karena keputusan penggunaan lahan bukan hanya ditentukan oleh karakteristik lahan, namun juga keinginan/Prioritas pemangku kepentingan (Bordy, 2011; Feick dan Hall, 2002; Malczewski, 2006 dalam Omo-Irabor, 2011; Susskind dan Cruikshank, 1987 dalam Brody, 2006; Schmoldt et al., 2001).

Prioritas pemangku kepentingan diperoleh dari hasil wawancara kepada responden yang diminta membandingkan kriteria secara berpasangan (lihat Lampiran 1) untuk selanjutnya dianalisis dengan teknik AHP sehingga diperoleh bobot per kriteria. Analisis dengan teknik AHP akan menghasilkan nilai eigenvalue beserta nilai consistency index (CI). Dalam AHP, nilai eigenvalue merupakan bobot kriteria; sedangkan CI mencerminkan tingkat konsistensi dari penilaian bobot para pemangku kepentingan yang selanjutnya akan diturunkan menjadi nilai consistency ratio (CR) dengan membandingkan nilai CI dengan nilai random index (RI) (Tabel 11). Tabel 12 merangkum bobot kriteria, CI, dan CR setiap responden.

Berdasarkan perbandingan kriteria berpasangan, aspek sosial merupakan kriteria yang menjadi prioritas utama bagi pemangku kepentingan di level lokal (kelompok mangrove, petani tambak, dan tokoh masyarakat). Lihat Tabel 13 Hasil ini berbeda dari perkiraan peneliti bahwa kelompok mangrove akan memprioritaskan aspek fisik, petani tambak memprioritaskan aspek pembiayaan, dan tokoh masyarakat memprioritaskan aspek sosial. 
Tabel 10. Responden dalam penelitian

\begin{tabular}{|c|c|c|}
\hline Pemangku Kepentingan & Jumlah & Keterangan \\
\hline Kelompok mangrove & 5 & $\begin{array}{l}\text { Seluruhnya merupakan ketua kelompok mangrove. Kelompok mangrove } \\
\text { yang peneliti pilih adalah kelompok mangrove yang masih aktif. }\end{array}$ \\
\hline Petani tambak & 3 & $\begin{array}{l}\text { Seluruhnya merupakan petani tambak. Budidaya tambak yang utama di } \\
\text { Kabupaten Demak yaitu pada Kecamatan Wedung, Bonang, dan } \\
\text { Karangtengah. Maka pada penelitian ini, pada kecamatan-kecamatan tersebut } \\
\text { diambil masing-masing } 1 \text { kelompok tambak. }\end{array}$ \\
\hline Tokoh masyarakat & 6 & $\begin{array}{l}\text { Seluruhnya merupakan perangkat desa, diutamakan kepala desa atau } \\
\text { sekretaris desa. Sebagian berasal dari desa yang berbatasan langsung dengan } \\
\text { laut, sebagian lagi tidak berbatasan langsung dengan laut. }\end{array}$ \\
\hline Pemerintah daerah & 3 & $\begin{array}{l}\text { Instansi-instansi yang lingkup kerja dan kewenangannya berkaitan dengan } \\
\text { mangrove, yaitu: } \\
\text { - Kepala Bidang Kelautan, Dinas Kelautan dan Perikanan } \\
\text { - Kepala Bidang Fisik dan Prasarana, BAPPEDA (bidang Fisik dan } \\
\text { Prasarana merupakan bidang penanggung jawab penyusunan RTRW) } \\
\text { - Kepala Bidang Kehutanan, Dinas Pertanian }\end{array}$ \\
\hline
\end{tabular}

Tabel 11. Random Index AHP

\begin{tabular}{cccccccccccc}
\hline $\mathrm{n}$ & 1 & 2 & 3 & 4 & 5 & 6 & 7 & 8 & 9 & 10 & 9 \\
$\mathrm{RI}$ & 0 & 0 & 0,58 & 0,9 & 1,12 & 1,24 & 1,32 & 1,41 & 1,45 & 1,49 \\
\hline
\end{tabular}

Tabel 12. Bobot kriteria, CI, dan CR Responden

\begin{tabular}{|c|c|c|c|c|c|c|}
\hline \multirow{2}{*}{ Responden } & \multicolumn{3}{|c|}{ Bobot Kriteria } & \multirow[b]{2}{*}{ Ancaman } & \multirow{2}{*}{$\mathrm{Ci}$} & \multirow{2}{*}{$\begin{array}{c}\text { Keterangan } \\
\mathrm{Ci}^{\star}\end{array}$} \\
\hline & Fisik & Sosial & Biaya & & & \\
\hline \multicolumn{7}{|c|}{ Kelompok Mangrove } \\
\hline M01 & 0.30176 & 0.57236 & 0.06503 & 0.06084 & 0.04037 & Konsisten \\
\hline M02 & 0.12095 & 0.60476 & 0.04572 & 0.22858 & 0.34124 & Konsisten \\
\hline M03 & 0.43803 & 0.18779 & 0.17229 & 0.20189 & 1.70774 & Tidak konsisten \\
\hline M04 & 0.33139 & 0.30029 & 0.06472 & 0.3036 & 1.24049 & Tidak konsisten \\
\hline M05 & 0.35996 & 0.15297 & 0.17812 & 0.30896 & 1.19377 & Tidak konsisten \\
\hline \multicolumn{7}{|c|}{ Petani Tambak } \\
\hline TB01 & 0.24248 & 0.10277 & 0.62172 & 0.03302 & 0.19511 & Konsisten \\
\hline TB02 & 0.11479 & 0.54679 & 0.18879 & 0.14963 & 1.0242 & Tidak konsisten \\
\hline TB03 & 0.04403 & 0.62117 & 0.15391 & 0.18089 & 0.25781 & Konsisten \\
\hline \multicolumn{7}{|c|}{ Tokoh Masyarakat } \\
\hline TH01 & 0.42544 & 0.43905 & 0.10322 & 0.0323 & 0.24899 & Konsisten \\
\hline TH02 & 0.0439 & 0.61842 & 0.10008 & 0.23759 & 0.18357 & Konsisten \\
\hline TH03 & 0.27402 & 0.17706 & 0.03915 & 0.50977 & 0.16883 & Konsisten \\
\hline TH04 & 0.20862 & 0.08172 & 0.1983 & 0.51135 & 0.34758 & Konsisten \\
\hline TH05 & 0.08057 & 0.22607 & 0.16214 & 0.53122 & 0.48744 & Konsisten \\
\hline TH06 & 0.05756 & 0.26237 & 0.19858 & 0.48149 & 0.24488 & Konsisten \\
\hline \multicolumn{7}{|c|}{ Pemerintah Daerah } \\
\hline PM01 & 0.21286 & 0.27519 & 0.38792 & 0.12403 & 2.12401 & Tidak konsisten \\
\hline PM02 & 0.08057 & 0.22607 & 0.16214 & 0.53122 & 0.47077 & Konsisten \\
\hline PM03 & 0.05191 & 0.34432 & 0.55596 & 0.04781 & 0.0756 & Konsisten \\
\hline
\end{tabular}

Sumber : Analisa Data (2014)

${ }^{\star}$ Dikatakan konsisten jika CI bernilai 0 atau mendekati 0 . Tidak konsisten jika bernilai > 1

Kelompok mangrove dan petani tambak memberikan bobot terbesar pada aspek sosial dengan nilai 0,3636 (kelompok mangrove) dan 0,4235 (petani tambak); sedangkan tokoh masyarakat memberikan bobot untuk aspek sosial 0,3007 -meskipun bobot terbesar pada aspek ancaman 0,3839. Hal ini dikarenakan para pemangku kepentingan, bagaimanapun juga, turut memposisikan diri mereka sebagai anggota masyarakat serta melihat secara realistis kondisi di lapangan. Meskipun kriteria prioritas utama cenderung homogen, kriteria yang menjadi prioritas II bervariasi. Kelompok mangrove memprioritaskan aspek fisik, petani tambak memprioritaskan aspek pembiayaan, dan tokoh masyarakat memprioritaskan aspek sosial. 
Prioritas yang berbeda terdapat pada pemangku kepentingan dari pemerintah daerah, yang memberikan bobot terbesar pada aspek pembiayaan 0,3686 . Hal ini dikarenakan dalam lingkup instansi pemerintahan, biaya merupakan faktor kunci pendorong sekaligus penghambat jalannya program/kegiatan, termasuk didalamnya program rehabilitasi dan konservasi mangrove. Tanpa adanya dukungan biaya, meskipun terdapat hamparan lahan yang potensial untuk pertumbuhan mangrove, maka program rehabilitasi dan konservasi mangrove tidak akan terlaksana. Pemerintah daerah selanjutnya menempatkan aspek sosial sebagai prioritas II $(0,2818)$, karena pemerintah daerah menyadari bahwa keberlanjutan suatu program sangat bergantung pada dukungan dari masyarakat. Keberlanjutan program sendiri penting bagi pemerintah daerah karena terkait dengan monitoring program, terlebih lagi untuk program jangka panjang seperti rehabilitasi mangrove.

\section{Kawasan Konservasi Mangrove Terpilih}

\section{a. Peta-peta Kriteria}

Pemilihan kawasan konservasi mangrove dalam penelitian ini memperhitungkan empat aspek, yaitu aspek fisik, sosial, pembiayaan, dan ancaman. Keempat kriteria tersebut direpresentasikan dalam bentuk peta (Gambar 4) setelah sebelumnya dilakukan standardisasi data (lihat Tabel 4) sehingga menghasilkan nilai baru 0 (paling buruk) hingga 1 (paling baik).

Peta aspek fisik diperoleh dari analisis kesesuaian lahan, dengan kelas kesesuaian lahan pada wilayah kajian terdiri dari kelas sesuai dan sesuai marginal. Karena hanya terdapat dua kelas kesesuaian lahan, maka nilai kesesuaian lahan terstandardisasi hanya terdiri dari 1 (sesuai) dan 0 (sesuai marginal). Dapat dilihat pada Gambar 4a bahwa hampir seluruh wilayah kajian termasuk dalam kelas sesuai untuk pertumbuhan mangrove.

Berbeda dengan aspek fisik yang cenderung homogen (94,8\% termasuk kelas sesuai), aspek sosial di wilayah kajian cukup bervariasi. Nilai aspek sosial paling tinggi terdapat di wilayah Kecamatan Wedung, Bonang, dan Karangtengah (Gambar 4b). Hal ini dikarenakan persentase penduduk yang bermata pencaharian di sektor primer relatif sedikit dan lahan di wilayah pantai di Kecamatan Wedung dan Bonang sebagian besar merupakan tanah timbul yang merupakan milik negara. Untuk wilayah Kecamatan Karangtengah, lahan dengan nilai aspek sosial tinggi berada di bantaran Sungai Tuntang, yang juga merupakan tanah milik negara.

Serupa dengan aspek sosial, nilai aspek pembiayaan terbaik (pembiayaan relatif kecil, bernilai 1 pada hasil standardisasi) terdapat di wilayah Kecamatan Wedung dan Bonang (Gambar 4c), hal ini terutama karena adanya tanah timbul sehingga jika tanah tersebut akan dimanfaatkan sebagai kawasan konservasi mangrove tidak diperlukan biaya pembebasan lahan. Selain itu, gelombang di wilayah pantai Kecamatan Bonang dan Wedung relatif lebih kecil dibandingkan wilayah pantai Kecamatan Sayung (terutama di Desa Bedono). Pengukuran tinggi gelombang yang dilakukan pada saat survei lapangan (pada musim timur) menunjukkan bahwa gelombang tertinggi terdapat di perairan pantai Desa Bedono yang tinggi gelombangnya mencapai $20 \mathrm{~cm}$ pada sore hari. Nilai ini lebih besar dibandingkan gelombang di sekitar Pelabuhan Perikanan Pantai (PPP) Morodemak yang mencapai $6 \mathrm{~cm}$ dan muara Sungai Menco Wedung yang mencapai $5 \mathrm{~cm}$. Untuk melakukan penanaman pada wilayah dengan gempuran ombak yang cukup besar, diperlukan bangunan pelindung pantai, baik terbuat dari bambu, kayu, ban bekas, ataupun beton (Gambar 5). Bangunan pelindung pantai dari kayu pernah dibuat, namun hanya bertahan 1 tahun akibat diterjang ombak serta material kayu yang membusuk akibat pengaruh air laut dan hewan perairan yang oleh warga disebut dengan runti. Inilah yang mengakibatkan besarnya biaya pengembangan kawasan konservasi mangrove di pantai dengan ombak yang besar.

Meskipun nilai aspek sosial dan pembiayaannya cukup baik, wilayah Kecamatan Wedung memiliki nilai ancaman yang relatif lebih besar (nilai ancaman terstandardisasi mendekati 0) dibandingkan wilayah lainnya (Gambar 4d). Hal ini dikarenakan \%KPS di Kecamatan Wedung relatif lebih besar dibandingkan Kecamatan Bonang, Karangtengah, dan Sayung. Tingginya tingkat kemiskinan merupakan potensi ancaman karena warga miskin cenderung mengeksploitasi sumberdaya alam. Dalam penelitiannya, Ma'mun (2011) menemukan bahwa makin rendah tingkat pendapatan, makin tinggi pemanfaatan kayu mangrove. Kecenderungan mengeksploitasi sumberdaya alam juga terlihat di Kecamatan Wedung. Lahan yang semula berupa tutupan lahan mangrove dibabati menjadi lahan tambak ikan/udang, dan pada beberapa lokasi yang lahan tambaknya (tambak ikan/udang) sudah tidak produktif, difungsikan menjadi tambak garam. 
Tabel 13. Bobot Kriteria Menurut Pemangku Kepentingan

\begin{tabular}{lrccc}
\hline Pemangku Kepentingan & Aspek Fisik & Aspek Sosial & $\begin{array}{c}\text { Bobot Kriteria } \\
\text { Aspek Pembiayaan }\end{array}$ & Aspek Ancaman \\
\hline Kelompok Mangrove & 0,3104 & 0,3636 & 0,1051 & 0,2207 \\
Petani Tambak & 0,1337 & 0,4235 & 0,3214 & 0,1211 \\
Tokoh Masyarakat & 0,1816 & 0,3007 & 0,1335 & 0,3839 \\
Pemerintah Daerah & 0,1151 & 0,2818 & 0,3686 & 0,2343 \\
\hline
\end{tabular}

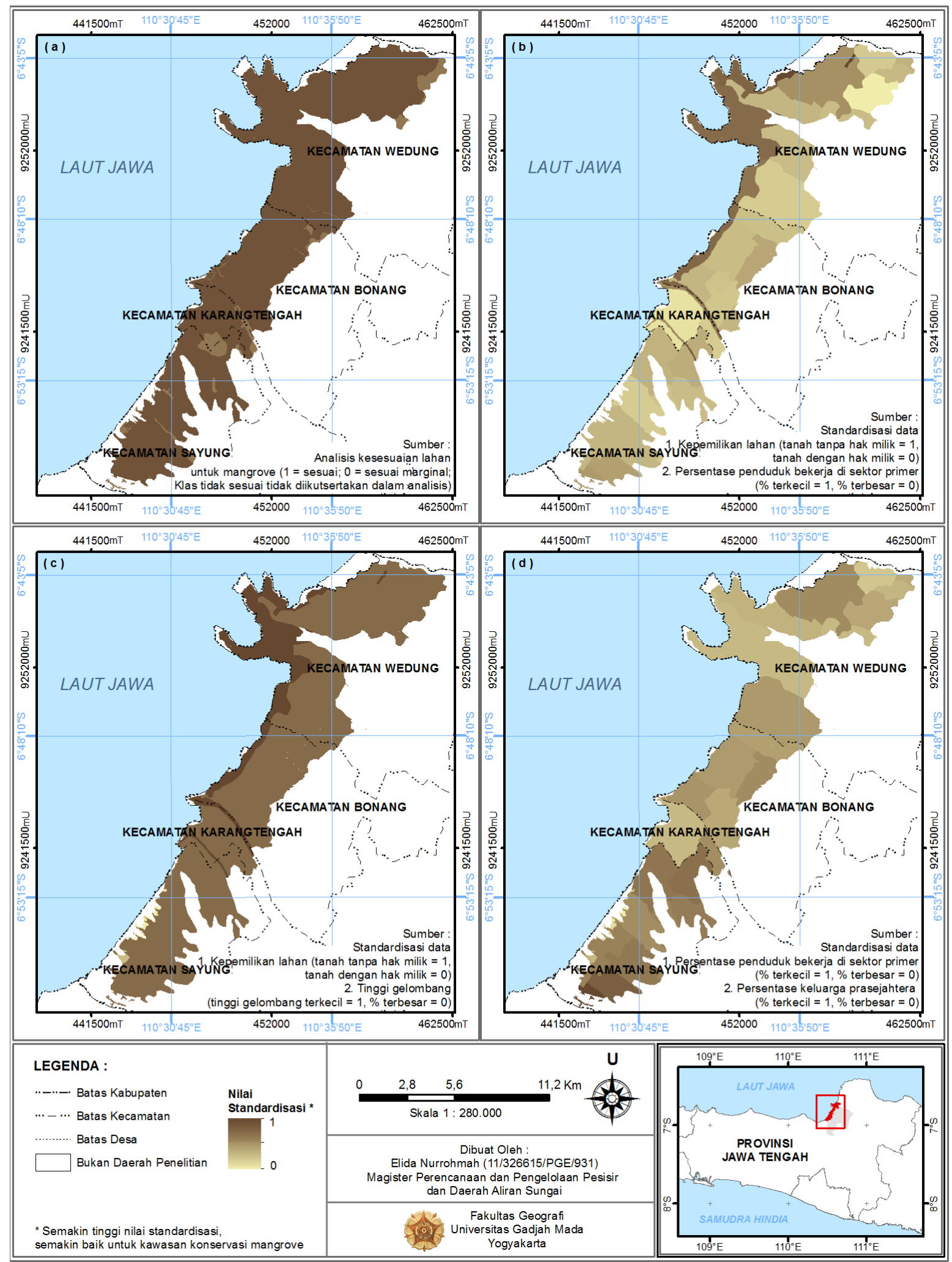

Gambar 4. Peta Kriteria Fisik (a), Sosial (b), Pembiayaan (c), dan Ancaman (d) Untuk Pemilihan Lokasi Kawasan Konservasi Mangrove 


\section{b. Lokasi Kawasan Konservasi Mangrove Terpilih}

Perkalian nilai cell dengan bobot kriteria (Tabel 13) memberikan luaran lokasi kawasan konservasi mangrove terpilih menurut prioritas setiap pemangku kepentingan (Gambar 6), yang dikategorikan menjadi 5 kelas (Tabel 5). Rincian luas lahan terpilih oleh masingmasing pemangku kepentingan tersaji pada Tabel 14
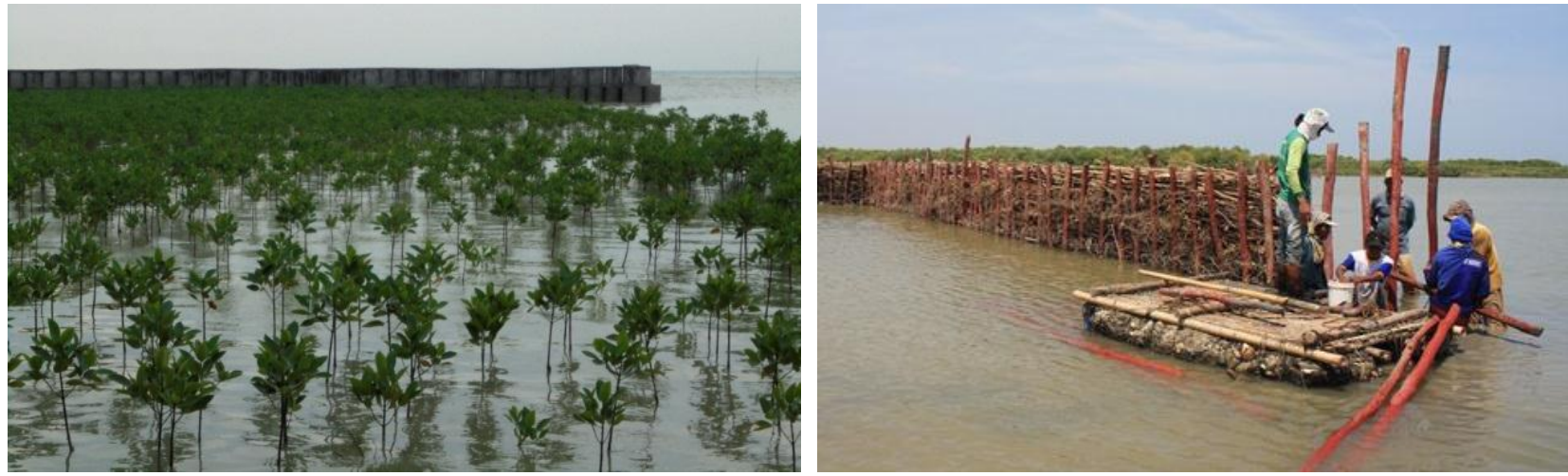

Gambar 5. Bangunan Pelindung Pantai Dari Beton (a) dan Kayu (b) di Desa Timbulsloko

Dokumentasi : (a) survei lapangan, 2014; (b) http://www.radarsemarang.com/2015/07/16/pecah-ombak-denganhybrid-engineering.html)

Tabel 14. Luas Lahan Terpilih untuk Konsevasi Mangrove Menurut Prioritas Pemangku Kepentingan

\begin{tabular}{|c|c|c|c|c|c|c|c|c|c|c|}
\hline \multirow{2}{*}{ Kecamatan } & \multicolumn{10}{|c|}{ Luas Lahan Terpilih (ha) per Kategori } \\
\hline & Prioritas I & $\%^{*}$ & Prioritas II & $\%^{*}$ & Prioritas III & $\%^{*}$ & Prioritas IV & $\%^{*}$ & Prioritas V & $\% *$ \\
\hline \multicolumn{11}{|c|}{ Kelompok Budidaya Mangrove } \\
\hline Bonang & 116.9 & 65.6 & 482.5 & 10.6 & $1,702.50$ & 25.3 & 64.3 & 13.7 & 0 & 0 \\
\hline Karangtengah & 0 & 0 & 72.6 & 1.6 & 707.1 & 10.5 & 43.7 & 9.3 & 58.1 & 57.4 \\
\hline Sayung & 4.9 & 2.8 & $1,654.00$ & 36.4 & $1,253.50$ & 18.6 & 210 & 44.7 & 3.9 & 3.9 \\
\hline Wedung & 56.2 & 31.6 & $2,335.80$ & 51.4 & $3,069.30$ & 45.6 & 152.4 & 32.4 & 39.2 & 38.7 \\
\hline Total & 178 & 100 & $4,545.00$ & 100 & $6,732.30$ & 100 & 470.3 & 100 & 101.2 & 100 \\
\hline \multicolumn{11}{|l|}{ Petani Tambak } \\
\hline Bonang & 265.1 & 18.7 & 39.5 & 9.4 & $1,997.20$ & 24 & 64.3 & 3.5 & 0 & 0 \\
\hline Karangtengah & 0 & 0 & 94.2 & 22.4 & 139.4 & 1.7 & 647.8 & 35.1 & 0 & 0 \\
\hline Sayung & 4.9 & 0.3 & 72.8 & 17.3 & $2,781.10$ & 33.4 & 264.4 & 14.3 & 3.2 & 100 \\
\hline Wedung & $1,149.70$ & 81 & 213.7 & 50.9 & $3,418.60$ & 41 & 870.9 & 47.1 & 0 & 0 \\
\hline Total & $1,419.70$ & 100 & 420.2 & 100 & $8,336.30$ & 100 & $1,847.40$ & 100 & 3.2 & 100 \\
\hline \multicolumn{11}{|c|}{ Tokoh Masyarakat } \\
\hline Bonang & 0 & 0 & 271.6 & 8.3 & $2,030.20$ & 29.1 & 64.3 & 3.9 & 0 & 0 \\
\hline Karangtengah & 0 & 0 & 0 & 0 & 233.6 & 3.3 & 589.8 & 35.6 & 58.1 & 94.3 \\
\hline Sayung & 4.9 & 8.7 & 686.4 & 20.9 & $2,300.50$ & 33 & 131 & 7.9 & 3.5 & 5.7 \\
\hline Wedung & 51.7 & 91.3 & $2,320.10$ & 70.8 & $2,410.30$ & 34.6 & 870.9 & 52.6 & 0 & 0 \\
\hline Total & 56.6 & 100 & $3,278.00$ & 100 & $6,974.60$ & 100 & $1,655.90$ & 100 & 61.6 & 100 \\
\hline \multicolumn{11}{|c|}{ Pemerintah Daerah } \\
\hline Bonang & 222 & 78.4 & 82.6 & 4.5 & $2,006.20$ & 24.4 & 55.3 & 3.3 & 0 & 0 \\
\hline Karangtengah & 0 & 0 & 94.2 & 5.1 & 139.4 & 1.7 & 647.8 & 39.1 & 0 & 0 \\
\hline Sayung & 4.9 & 1.7 & 371.1 & 20 & $2,643.70$ & 32.2 & 80.8 & 4.9 & 25.9 & 100 \\
\hline Wedung & 56.2 & 19.9 & $1,307.10$ & 70.5 & $3,418.70$ & 41.7 & 870.9 & 52.6 & 0 & 0 \\
\hline Total & 283.1 & 100 & $1,855.10$ & 100 & $8,208.00$ & 100 & $1,654.80$ & 100 & 25.9 & 100 \\
\hline
\end{tabular}

Keempat peta yang telah dihasilkan tersebut ditumpangsusunkan kembali untuk memperoleh lokasi awasan konservasi terpilih yang memenuhi keinginan setiap pemangku kepentingan, dengan ketentuan seperti tertulis pada Tabel 15. Berdasarkan analisis tersebut, diperoleh bahwa lokasi yang paling memenuhi keinginan semua pemangku kepentingan hanya seluas 51,7 ha $(0,4 \%$ dari total luas wilayah kajian), yang tersebar di wilayah pantai Kecamatan Wedung (91,3\% dari total luas lahan prioritas I) tepatnya di Desa Babalan dan satu lokasi lagi terletak di tengah Desa Kedungmutih (lihat Gambar 7 dan Tabel 16).

Lahan ini dikategorikan sebagai lahan prioritas I, dimana pada analisis sebelumnya (pemilihan lokasi menurut prioritas masing-masing pemangku 
kepentingan) lahan tersebut merupakan lahan prioritas I. Penggunaan lahan eksisting pada lokasi tersebut merupakan lahan tambak, termasuk dalam kelas sesuai untuk pertumbuhan mangrove, merupakan tanah negara, dengan gelombang yang relatif kecil. Meskipun demikian, skor aspek ancaman pada lahan prioritas I ini masuk pada kategori 0,4 - 0,6 yang berarti tingkat ancamannya tergolong sedang.
Perangkat Desa Babalan menuturkan bahwa wilayahnya memang memerlukan upaya-upaya perlindungan pantai karena beberapa tahun terakhir ini wilayah Desa Babalan mengalami erosi pantai (Gambar 8) dan telah menggerus sebagian lahan tambak yang menjadi sumber penghidupan utama warga.

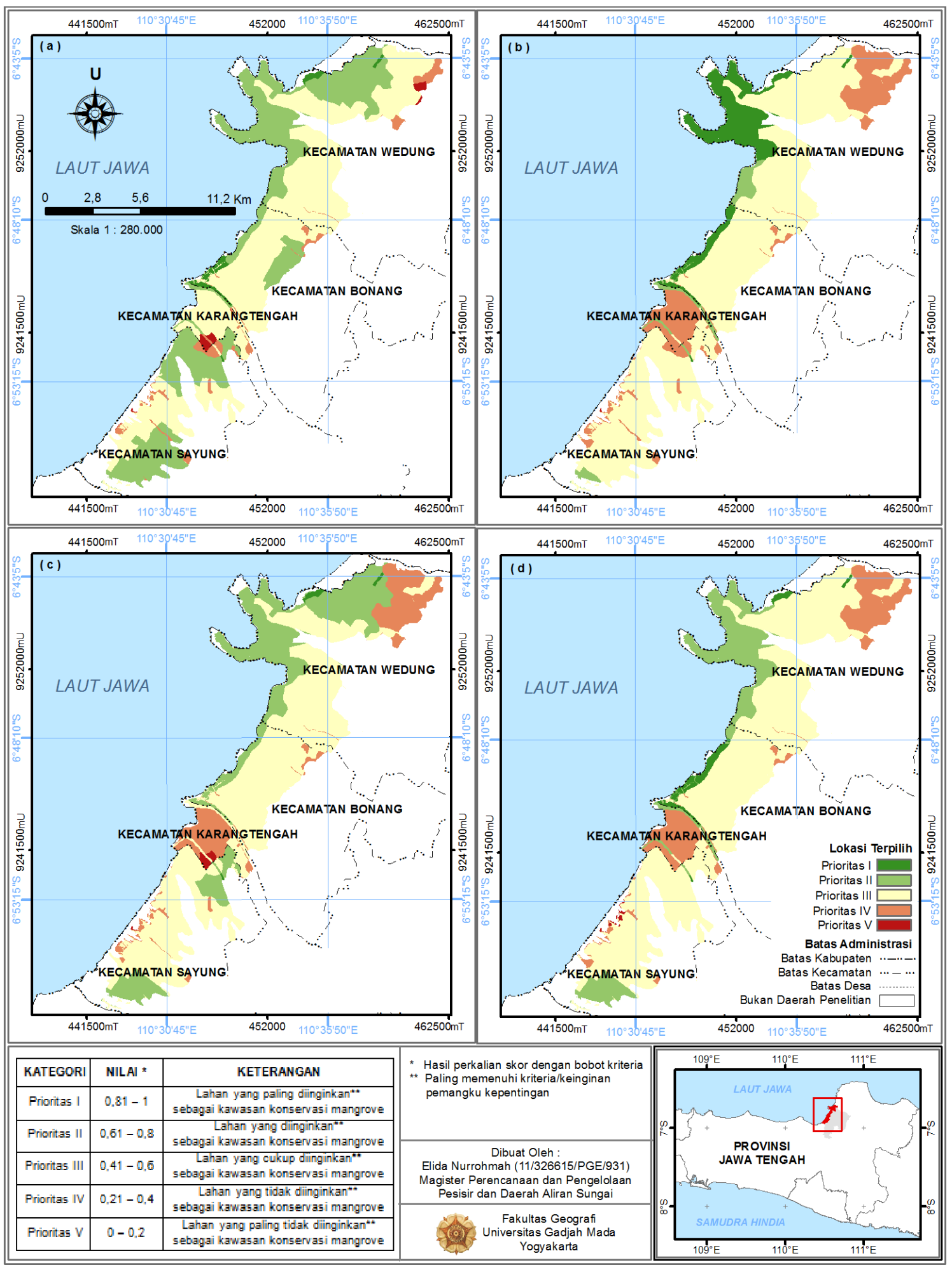

Gambar 6. Peta lokasi lahan terpilih untuk kawasan konservasi mangrove menurut prioritas (a) kelompok budidaya mangrove, (b) petani tambak, (c) tokoh masyarakat, dan (d) pemerintah daerah 
Tabel 15. Kategorisasi Skor Prioritas Lahan Terpilih Kombinasi Seluruh Pemangku Kepentingan

\begin{tabular}{llc}
\hline \multicolumn{1}{c}{ Kategori } & \multicolumn{1}{c}{ Keterangan } & Skor \\
\hline Prioritas I & $\begin{array}{l}\text { Seluruh pemangku kepentingan memilih lahan tersebut sebagai lahan prioritas I } \\
\text { (paling memenuhi keinginan/kriteria pemangku kepentingan). Kemungkinan }\end{array}$ & 20 \\
& konflik kecil. & $16-19$ \\
Prioritas II & $\begin{array}{l}\text { Sebagain besar pemangku kepentingan memilih lahan tersebut sebagai lahan } \\
\text { prioritas I dan/atau II (memenuhi keinginan/kriteria pemangku kepentingan). }\end{array}$ & $12-15$ \\
Prioritas III & Sebagain besar pemangku kepentingan memilih lahan tersebut sebagai lahan \\
& prioritas III (cukup memenuhi keinginan/kriteria pemangku kepentingan). \\
Tidak diprioritaskan & Tidak diprioritaskan karena hampir semua pemangku kepentingan mengkategorikan \\
& $\begin{array}{l}\text { laan tersebut sebagai lahan prioritas IV (tidak memenuhi keinginan/kriteria } \\
\text { pemangku kepentingan). }\end{array}$ & $<11$ \\
\hline
\end{tabular}

Tabel 16. Deskripsi Lahan Terpilih Kombinasi Seluruh Pemangku Kepentingan

\begin{tabular}{|c|c|c|c|}
\hline PRIORITAS LAHAN & LUAS $^{\star}$ (ha) & $\%^{\star *}$ & LOKASI \\
\hline Prioritas I & 56,6 & 0,5 & $\begin{array}{l}\text { - Wilayah pantai Desa Babalan } \\
\text { - Salah satu tambak garam di Desa } \\
\text { Kedungmutih }\end{array}$ \\
\hline Prioritas II & $1.626,9$ & 13,5 & $\begin{array}{l}\text { - Sekitar wilayah PPP Morodemak } \\
\text { - Wilayah pantai Desa Purworejo dan } \\
\text { Betahwalang (Kecamatan Bonang)Wilayah } \\
\text { pantai Desa Wedung (Kecamatan Wedung) } \\
\text { - Wilayah pantai dan tanah timbul di muara } \\
\text { Sungai Wulan (Berahan Kulon, Berahan } \\
\text { Wetan) } \\
\text { - Wilayah Desa Sriwulan }\end{array}$ \\
\hline Prioritas III & $8.476,0$ & 70,5 & $\begin{array}{l}\text { - Hampir seluruh wilayah Desa Bedono, } \\
\text { Timbulsloko, Sidorejo, Sidogemah, Tugu, } \\
\text { Gebang, Margolinduk, Betahwalang, Bungo }\end{array}$ \\
\hline Tidak diprioritaskan & $1.867,2$ & 15,5 & $\begin{array}{l}\text { - Seluruh wilayah Desa Kendalasem, Mutih } \\
\text { Kulon, Tambakbulusan } \\
\text { - Hutan mangrove di Desa Bedono }\end{array}$ \\
\hline
\end{tabular}

* Untuk rincian luas lahan terpilih kombinasi seluruh pemangku kepentingan, lihat Lampiran

** Persentase luas lahan terhadap total luas wilayah kajian

Sumber : Analisis Data (2014)

Lahan prioritas I lainnya berada di lahan tambak garam Desa Kedungmutih. Meskipun terletak di tengah daratan, lahan ini mendapat pasokan air laut yang memang sengaja dialirkan melalui saluransaluran air yang terhubung dengan sungai. Berbeda dengan masyarakat Desa Babalan yang memang merasa membutuhkan penanaman mangrove, masyarakat Desa Kedungmutih kurang merasa butuh akan mangrove. Hal ini karena wilayah Desa Kedungmutih tidak mei erosi pantai dan selama tambak garam masih produktif masyarakat Desa Kedungmutih masih memperoleh sumber penghidupan. Maka, bentuk penanaman mangrove yang paling memungkinkan di desa ini yaitu penanaman mangrove pada pematang-pematang tambak.

Lahan prioritas II diperoleh dari hasil analisis didapat seluas $1.626,9$ ha $(13,5 \%$ dari total luas wilayah kajian). Lahan yang dikategorikan sebagai lahan prioritas II adalah lahan yang pada analisis sebelumnya (pemilihan lokasi menurut prioritas masing-masing pemangku kepentingan) terpilih sebagai lahan prioritas II pada semua pemangku kepentingan ataupun lahan yang terpilih sebagai lahan prioritas I pada sebagian pemangku kepentingan dan lahan prioritas II pada sebagian pemangku kepentingan yang lain. Lahan prioritas II tersebar di Kecamatan Wedung (79,4\% dari total luas lahan prioritas II), Bonang (16,7\%), dan Sayung (3,9\%). Lahan prioritas II di Kecamatan Wedung berada di Desa Berahan Kulon, Berahan Wetan, Wedung, dan Babalan. Seluruh lokasi terpilih tersebut merupakan lahan dengan kelas sesuai untuk pertumbuhan mangrove. Sebagian terletak pada tanah hak milik, dengan ancaman yang relatif besar. Di Kecamatan Bonang, lahan prioritas II terletak di Desa Morodemak, Purworejo, Betahwalang, dan Gebang. Penggunaan lahan eksisting seluruhnya berupa lahan tambak ikan/udang.

Lahan prioritas III diperoleh seluas 8.476 ha $(70,5 \%$ dari total luas wilayah kajian). Lahan-lahan tersebut 
pada analisis sebelumnya terpilih sebagai lahan prioritas III pada semua pemangku kepentingan ataupun lahan terpilih sebagai lahan prioritas II pada sebagian pemangku kepentingan dan lahan prioritas III pada sebagian pemangku kepentingan yang lain. Lahan prioritas III tersebar di Kecamatan Wedung (40,6\% dari total luas lahan prioritas III), Sayung (32,9\%),
Bonang (24\%), dan sebagian kecil di Karangtengah $(2,6 \%)$. Lahan-lahan prioritas III sebagian kecil terletak pada kelas sesuai marginal untuk pertumbuhan mangrove, dengan ancaman yang relatif besar dan status kepemilikan lahan bervariasi baik tanah hak milik maupun tanah milik negara.

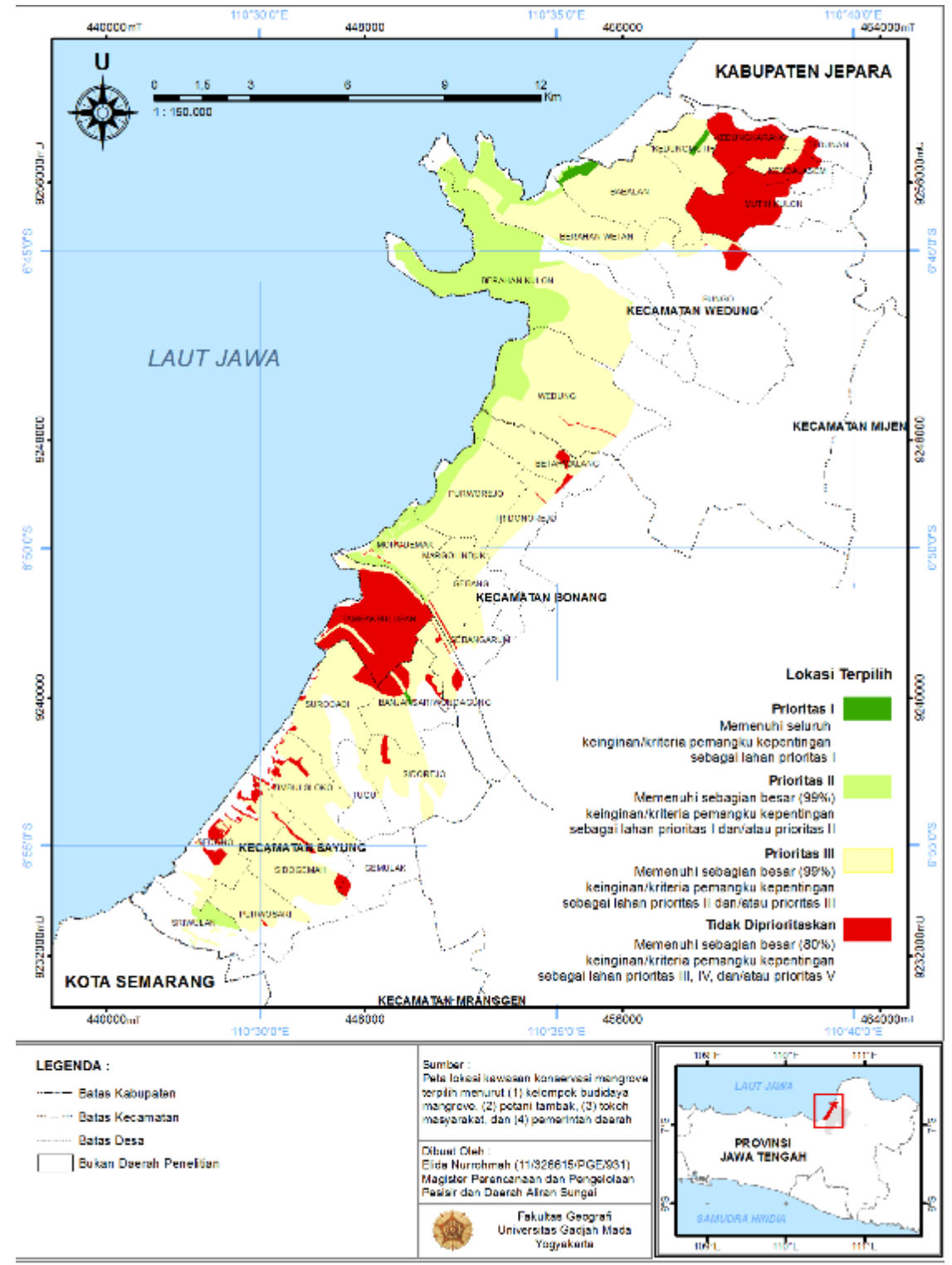

Gambar 7. Peta Lokasi Lahan Terpilih untuk Kawasan Konservasi Mangrove Kombinasi Seluruh para Pemangku Kepentingan

Tabel 17. Luas Lahan Terpilih Kombinasi Seluruh Pemangku Kepentingan

\begin{tabular}{lcccccccc}
\hline \multirow{2}{*}{ Kecamatan } & \multicolumn{8}{c}{ Luas Lahan Terpilih (ha) per Kategori } \\
& Prioritas I & $\%^{*}$ & Prioritas II & $\%^{*}$ & Prioritas III & $\%^{*}$ & Tidak Diprioritaskan & $\%^{*}$ \\
\hline Bonang & 0 & 0 & 271.6 & 16.7 & $2,030.20$ & 24 & 64.3 & 3.4 \\
Karangtengah & 0 & 0 & 0 & 0 & 218.5 & 2.6 & 662.9 & 35.5 \\
Sayung & 4.9 & 8.7 & 64 & 3.9 & $2,788.30$ & 32.9 & 269.1 & 14.4 \\
Wedung & 51.7 & 91.3 & $1,291.30$ & 79.4 & $3,439.00$ & 40.6 & 870.9 & 46.6 \\
Total & 56.6 & 100 & $1,626.90$ & 100 & $8,476.00$ & 100 & $1,867.20$ & 100 \\
\hline
\end{tabular}

*\% terhadap luas lahan per kategori prioritas;

Sumber : Tumpangsusun peta lokasi lahan terpilih gabungan seluruh pemangku kepentingan dengan peta batas administrasi 

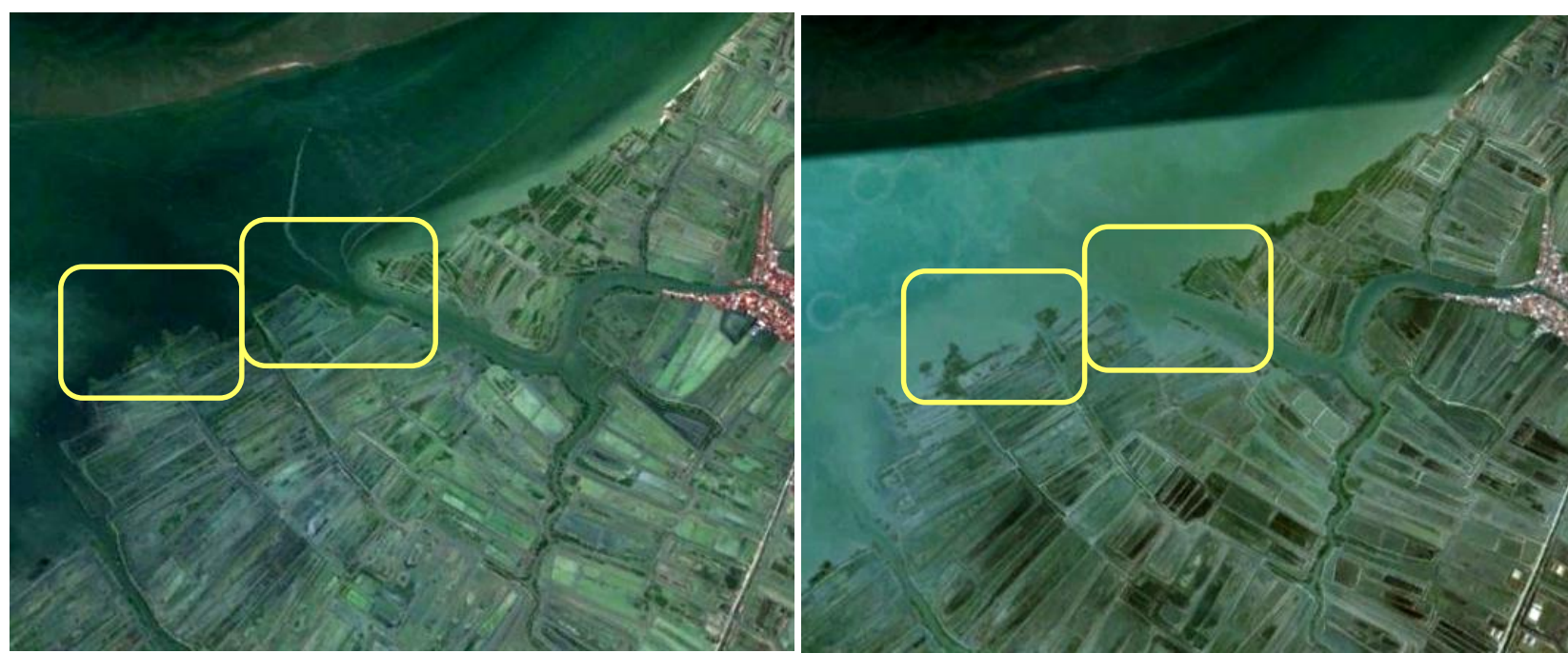

Gambar 8. Capture citra Quickbird wilayah pantai Desa Babalan perekaman tanggal (a) 5 Januari 2010, (b) 9 September 2012 (dikompilasi oleh Google Earth)

Tabel 18. Deskripsi Faktor Pendukung dan Penghambat pada Lahan Terpilih Kombinasi Seluruh Pemangku Kepentingan

\begin{tabular}{|c|c|c|}
\hline Prioritas Lahan & Faktor Pendukung & Faktor Penghambat \\
\hline Prioritas I & $\begin{array}{l}\text { - Seluruhnya pada lahan dengan kelas sesuai untuk } \\
\text { mangrove } \\
\text { - Gelombang relatif kecil } \\
\text { - Tanah negara (tanah timbul, bantaran sungai) } \\
\text { - Jumlah penduduk bermata pencaharian pada sektor } \\
\text { primer sangat sedikit } \\
\text { - Jumlah keluarga prasejahtera dan sejahtera I sangat sedikit }\end{array}$ & \\
\hline Prioritas II & $\begin{array}{l}\text { - Seluruhnya pada lahan dengan kelas sesuai untuk } \\
\text { mangrove } \\
\text { - Gelombang relatif kecil } \\
\text { - Tanah tanpa hak milik } \\
\text { - Jumlah penduduk bermata pencaharian pada sektor } \\
\text { primer relatif sedikit }\end{array}$ & $\begin{array}{l}\text { - Sebagian kecil lahan berada pada tanah } \\
\text { hak milik } \\
\text { - Jumlah penduduk yang bekerja di sektor } \\
\text { primer relatif banyak } \\
\text { - Jumlah keluarga prasejahtera relatif } \\
\text { banyak }\end{array}$ \\
\hline Prioritas III & $\begin{array}{l}\text { - Sebagian lahan terletak pada lahan dengan kelas sesuai } \\
\text { untuk mangrove }\end{array}$ & $\begin{array}{l}\text { - Sebagian kecil pada lahan dengan kelas } \\
\text { sesuai marginal untuk mangrove } \\
\text { - Gelombang relatif besar } \\
\text { - Tanah hak milik } \\
\text { - Jumlah keluarga prasejahtera relatif } \\
\text { banyak } \\
\text { - Jumlah penduduk bermata pencaharian } \\
\text { pada sektor primer relatif banyak }\end{array}$ \\
\hline Tidak diprioritaskan & $\begin{array}{l}\text { - Sebagian lahan terletak pada lahan dengan kelas sesuai } \\
\text { untuk mangrove }\end{array}$ & $\begin{array}{l}\text { - Sebagian lahan terletak pada lahan } \\
\text { dengan kelas sesuai marginal untuk } \\
\text { mangrove } \\
\text { - Gelombang relatif besar } \\
\text { - Tanah hak milik } \\
\text { - Jumlah keluarga prasejahtera relatif } \\
\text { banyak } \\
\text { - Jumlah penduduk bermata pencaharian } \\
\text { pada sektor primer relatif banyak }\end{array}$ \\
\hline
\end{tabular}

\section{KESIMPULAN}

1. Sebagian besar $(94,8 \%)$ daerah penelitian sesuai secara fisik untuk pertumbuhan mangrove; dan selebihnya merupakan lahan yang sesuai marginal. Faktor pembatas bagi lahan-lahan dengan kelas sesuai marginal yaitu parameter salinitas (dibawah batas minimal), kadar bahan tersuspensi (dibawah batas minimal), dan suhu perairan (melebihi batas maksimal). Selain bentuklahan dan penggunaan lahan, penggenangan air laut juga menjadi faktor 
yang mempengaruhi kesesuaian suatu lahan untuk mangrove. Hal ini terlihat dari sebaran lahan dengan kelas sesuai untuk mangrove yang berada pada bentuklahan dataran delta dan rataan lumpur, serta sebagian dataran aluvial pantai. Dataran aluvial pantai yang sesuai untuk mangrove adalah dataran aluvial pantai yang secara periodik tergenang air laut (penggunaan lahan tambak ikan/udang, tambak garam, sungai, permukiman, dan sawah).

2. Pemangku kepentingan pada tingkat lokal lebih memprioritaskan aspek sosial dibandingkan aspek fisik, pembiayaan, dan ancaman; sedangkan pemerintah daerah lebih memprioritaskan aspek pembiayaan. Aspek sosial menjadi prioritas utama bagi pemangku kepentingan di tingkat lokal karena terkait dengan aset penghidupan; sedangkan aspek pembiayaan menjadi prioritas utama bagi pemerintah daerah karena terkait dengan tugas pokok dan fungsi serta regulasi.

3. Lokasi kawasan konservasi mangrove yang paling memenuhi prioritas para pemangku kepentingan (prioritas I) hanya didapati seluas 51,7 ha $(0,4 \%$ dari total luas wilayah kajian); terletak di salah satu lahan tambak di tepi pantai Desa Babalan serta lahan tambak garam di Desa Kedungmutih, Kecamatan Wedung. Lokasi terpilih ini tidak memiliki faktor penghambat dari aspek fisik, penerimaan secara sosial baik, pembiayaan relatif kecil, dan potensi ancaman kecil.

\section{DAFTAR PUSTAKA}

Abbot, J., Chambers R., Dunn C., Harris T., Merode E., Porter G., Townsend J., dan Weiner D. (1998). Participatory GIS: Opportunity or Oxymoron?. Participatory Learning and Action (PLA) Notes. 33.

Anonim(a). (2012). Pemberdayaan Masyarakat sebagai Strategi Pelestarian Kawasan Konservasi. Diakses tanggal 15 Juli 2014 dari situs http://bksdakaltim.dephut.go.id.

Arifin. (2012). Perumusan Zonasi Risiko Bencana Banjir Rob di Wilayah Pesisir Kabupaten Demak, Jawa Tengah. Skripsi: Institut Teknologi Sepuluh November.

Brody, S.D., Grover H., Bernhardt S., Tang Z., Whitaker B., Spence C. (2006). "Identifying Potential Conflict Associated with Oil and Gas Exploration in Texas State Coastal Waters: A Multicriteria Spatial Analysis". Environmental Management. 38, 597-617.

Dahuri, R., Rais, J., Ginting, S.P., dan Sitepu, M.J. (1996). Pengelolaan Sumber Daya Wilayah Pesisir dan Lautan Secara Terpadu. Jakarta: PT. Pradnya Paramita.

Departemen Kelautan dan Perikanan. (2005). Pedoman Mitigasi Bencana Alam di Wilayah Pesisir dan Pulau-pulau Kecil. Cetakan Kedua. Jakarta: Dirjen Pesisir dan Pulau-pulau Kecil Departemen Kelautan dan Perikanan.

Faturrohmah, S. (2014). Perencanaan Pemanfaatan Ruang Berbasis Konservasi Mangrove di Wilayah Kepesisiran Kabupaten Demak. Tesis. Universitas Gadjah Mada.

Fauzi. (2007). Model Peruntukan Kawasan Mangrove dengan Citra Penginderaan Jauh di Indragiri Hilir Riau. Tesis. Universitas Gadjah Mada.

Feick, R.D., Hal G.B. (2002). "Balancing Concesus and Conflict with a GIS-Based Multi-Participant, MultiCriteria Decision Support Tool”. GeoJournal. 53, 391-406.

Hapsari, N.I. (2013). Penataan Ulang Wilayah Kerja Resort Menggunakan Analisis Multikriteria (Studi Kasus di Taman Nasioanl Gunung Ciremai). Tesis. Universitas Gadjah Mada.

Hardjowigeno, S. dan Widiatmaka. (2011). Evaluasi Kesesuaian Lahan dan Perencanaan Tataguna Lahan. Yogyakarta: Gadjah Mada University Press.

Hidayat, T. (2013). Analisis Pengembangan Jalur Kereta Menuju Rencana Bandara Baru di Kulonprogo Yogyakarta. Tesis. Universitas Gadjah Mada.

International Fund for Agriculture Development (IFAD). (2009). Good Practice in Participatory Mapping. Diakses tanggal 1 Januari 2014 dari situs http://www.ifad.org/pub/map/pm_web.pdf.

Kay, R. dan Alder, J. (2005). Coastal Planning and Management. Edisi Kedua. New York: Taylor and Francis.

Kristanty, B. (2013). "Proyek REDD+ di Taman Nasional: Mengadopsi Model Satoyama”. 20 April 2013. Diakses tanggal 16 April 2014 dari situs http://www.blog.cifor.org.

Nybakken, J.W. (1992). Biologi Laut: Suatu Pendekatan Ekologi. Diterjemahkan oleh Edman, H.M. Jakarta: Gramedia.

Omo-Irabor, OmoO, Olobaniyi, S.B., Akunna, J., Venus, V., Maina, J.M., dan Paradzayi, C. (2011). "Mangrove vulnerability modelling in parts of Western Niger Delta, Nigeria using satellite images, GIS techniques and Spatial Analisis multikriteria (SMCA)". Environmental Monitoring and Assessment. 178, 39-51.

Ongkosongo, O.S.R. (2011). Strategi Menghadapi Risiko Bencana di Wilayah Pesisir Akibat 
Pemanasan Global dan Perubahan Iklim Global. Jakarta: LIPI.

Schmoldt, D. L., Kangas J., dan Mendoza, G.A. (2001). Basic Principles of Decision Making in Natural Resources and the Environment. Schmoldt, D.L., Kangas, J., Mendoza,G.A., dan Pesonen, M. (Ed).The Analytic Hierarchy Process in Natural Resource and Environmental Decision Making. Boston: Kluwer Academic Publishers.

Triatmodjo, B. (1999). Teknik Pantai. Yogyakarta: Beta Offset.

US Army Corps of Engineers. (1984). Shore Protection Manual Volume I. Edisi Keempat. Washington:
Department of the Army, US Army Corps of Engineers.

Zarkesh, M. K. (2005). Decision Support System for Floodwater Spreading Site Selection in Iran. Enschede: ITC.

Peraturan Perundang-undangan:

Undang-Undang Republik Indonesia Nomor 26 Tahun 2007 tentang Penataan Ruang, LNRI Tahun 2007 Nomor 84, TLNRI Nomor 4725.

Undang-Undang Republik Indonesia Nomor 27 Tahun 2007 tentang Pengelolaan Wilayah Pesisir dan Pulau-pulau Kecil, LNRI Tahun 2007 Nomor 84. TLNRI Nomor 4739. 